\title{
PENGOLAHAN AIR LINDI DENGAN PROSES BIOFILTER ANAEROB-AEROB DAN DENITRIFIKASI
}

\author{
Leachate Treatment Using Anaerobic-Aerobic Biofilter and Denitrification Process \\ Oleh : \\ Nusa Idaman Said dan Dinda Rita Krishumartani Hartaja \\ Pusat Teknologi Lingkungan, BPPT
}

\begin{abstract}
Abstrak
Pengolahan lindi sebagian besar TPA di Indonesia, masih menggunakan teknologi sistem kolam, yaitu menggunakan kolam penampung, kolam anaerobik, kolam aerobik, kolam stabilisasi, dan dilanjutkan dengan menggunakan wet land. Kelemahan teknologi tersebut adalah waktu tinggal yang relatif lama yakni antara 30 - 50 hari, sehingga bangunan kolam membutuhkan lahan yang cukup luas. Selain itu hasil olahan lindi masih di atas baku mutu yang diijinkan untuk dibuang ke badan lingkungan. Untuk mengatasi permasalahan tersebut, salah satu alternatif adalah pengolahan lindi dengan menggunakan kombinasi proses biofilter anaerob-aerob dan denitrifikasi. Dengan teknologi tersebut diharapkan mampu mempersingkat waktu tinggal, sehingga lahan yang diperlukan untuk pengolahan lindi tidak terlalu luas. Hasil olahan lindi juga diharapkan dapat memenuhi baku mutu yang diijinkan untuk dibuang ke lingkungan. Pengolahan air lindi menggunakan proses biofilter anaerob-aerob dan proses denitrifikasidengan total waktu 12 hari, yakni waktu tinggal di dalam reaktor anaerobik 8 (delapan) hari, waktu tinggal di dalam reaktor aerobik 3 (tiga) hari dan waktu tinggal di dalam reaktor denitrifikasi 1 (satu) hari dapat dihasilkan efisiensi penyisihan COD sebesar $97 \%$, efisiensi penyisihan amoniak $97,56 \%$, efisiensi penisihan TSS $87,5 \%$, dan efisiensi penyisihan nitrat sebesar $86,4 \%$
\end{abstract}

Kata Kunci : Biofilter anaerob-aerob, denitrifikasi, lindi.

\begin{abstract}
Most of the leachate treatment in Indonesia using pond system, that is maturation ponds, anaerobic ponds, stabilization ponds, and continued using wetland. The weakness of this technology is long retention time (between 30-50 days), thus the building a pond requires a wide area. In addition, the processed leachate is over quality standards to be discharged into the environment agency. To overcome these problems, one alternative is to use a combination of processing leachate within anaerobic-aerobic biofilter and denitrification. The technology is expected to shorten the residence time, so that the land required for the processing of leachate is not too extensive. The processed leachate is also expected to meet the quality standards are allowed to be discharged into the environment. Leachate treatment using anaerobic - aerobic biofilter and the denitrification process with a total hidraulic retention time of 12 day, the retention time in the anaerobic reactor 8 ( eight) days, the retention time in the aerobic reactor 3 (three) days and retention time in the denitrification reactor 1 (one) day can be generated COD removal efficiency of $97 \%$, ammonia removal efficiency of $97.56 \%$, TSS removal efficiency $87.5 \%$ , and nitrate removal efficiency of $86.4 \%$
\end{abstract}

Keywords : Anaerob-aerob biofilter, denitrification, leachate.

\section{PENDAHULUAN}

\subsection{Permasalahan Air Lindi}

Masalah lingkungan utama di lokasi tempat pembuangan akhir (TPA) sampah adalah infiltrasi air lindi dan selanjutnya akan mencemari tanah dan akuifer sekitarnya. Perbaikan di bidang teknologi TPA ditujukan untuk mengurangi produksi air indi, pengumpulan dan pengolahan air lindi sebelum dibuang ke perairan umum (Farquhar, 1989). Oleh karena itu, perlu mengembangkan pilihan opsi yang dapat diandalkan serta berkelanjutan dalam hal pegelolaan serta pengolahan air lindi yang efektif. Di dalam merancang sistem pengolahan air lindi maka prosesnya harus dapat mengolah air lindi yang berasal dari TPA untuk perioda yang lama. 
Saat ini pengelolaan sampah di Indonesia khususnya sampah domestik, sebagian besar menggunakan sistem TPA open dumping. Pada kondisi pengelolaan seperti ini, sebagian besar sampah hanya ditumpuk dalam suatu area TPA yang terbuka. Sehingga pada saat hujan, air rembesan sampah yang dikenal dengan air lindi akan keluar. Dan apabila tidak dikelola dan diolah dengan benar, maka akan berpotensi mencemari lingkungan sekitar.

Dalam kebanyakan TPA, air lindi terbentuk oleh rembesan kadar air dalam sampah maupun oleh sumber-sumber dari luar seperti pengaruh drainase, air hujan dan lain sebagainya yang melalui tumpukan sampah. Air lindi mengandung polutan padatan tersuspensi dan terlarut, zat - zat kimia baik organik maupun anorganik yang terkandung dalam sampah yang konsentrasinya cukup tinggi seperti amonia, nitrat, nitrit, sulfida, logam berat, nitrogen dan lain sebagainya. Dengan tingginya konsentrasi polutan, maka potensi pencemaran terhadap lingkungan sangat besar. Oleh karena itu perlu dicari teknologi yang tepat untuk dapat mengolah air lindi sampai air hasil olahannya tidak berbahaya terhadap lingkungan.

Pengolahan lindi sebagian besar TPA di Indonesia, masih menggunakan teknologi sistem kolam, yaitu menggunakan kolam penampung, kolam anaerobik, kolam aerobik, kolam stabilisasi, dan dilanjutkan dengan menggunakan wet land. Kelemahan teknologi tersebut adalah waktu tinggal yang relatif lama yakni antara 30 - 50 hari, sehingga bangunan kolam membutuhkan lahan yang cukup luas. Selain itu hasil olahan lindi masih di atas baku mutu yang diijinkan untuk dibuang ke badan lingkungan.

Dari permasalahan tersebut salah satu alternatif untuk mengatasi permasalahan tersebut adalah mengembangkan teknologi pengolahan lindi dengan menggunakan sistem biofilter anaerob aerob dan denitrifikasi. Dengan teknologi tersebut diharapkan mampu mempersingkat waktu tinggal, sehingga lahan yang diperlukan untuk pengolahan lindi tidak terlalu luas. Hasil olahan lindi juga diharapkan dapat memenuhi baku mutu yang diijinkan untuk dibuang ke badan lingkungan.

\subsection{Tujuan Penelitian}

Penelitian ini bertujuan untuk mengkaji efektifitas pengolahan air lindi dengan proses biofilter anerob-aerob dan proses denitrifikasi dengan menggunakan batu kapur dan belerang.Sedangkan sasaran dari penelitian ini adalah diperoleh data untuk mendesain teknologi proses yang tepat untuk mengolah air lindi yag dihasilkan oleh TPA.

\section{TINJAUAN PUSTAKA}

\subsection{Teknologi Pengolahan Lindi Di Indonesia}

Air lindi (leachate) adalah limbah cair yang timbul akibat masuknya air eksternal ke dalam timbunan sampah, melarutkan dan membilas materi - materi terlarut, termasuk juga materi organik hasil proses dekomposisi biologis. Dari sana dapat diramalkan bahwa kuantitas dan kualitas air lindi akan sangat bervariasi dan berfluktuasi (Rowe dan Booker, 1997). Air lindi dapat didefinisikan sebagai cairan yang menginfiltrasi melalui tumpukan sampah dan telah mengekstraksi material terlarut maupun tersuspensi (Tchobanoglous, 1993). Dikebanyakan tempat pembuangan akhir sampah (TPA), air lindi terbentuk dari cairan yang memasuki area landfill dari sumber - sumber eksternal, seperti drainase permukaan, air hujan, air tanah, dan cairan yang diproduksi dari dekomposisi sampah, sedangkan air lindi yang ditimbulkan dari kadar air yang terkandung dari dalam sampah dapat diabaikan dalam perhitungan, karena jumlahnya yang relatif kecil.

Air lindi secara luas dapat juga didefinisikan sebagai cairan yang dihasilkan dari dekomposisi sampah dan infiltrasi air hujan di TPA. Di dalam air lindi dapat mengandung senyawa logam berat, garam, senyawa nitrogen dan berbagai jenis bahan organik. Air Lindi adalah merupakan air limbah yang pekat atau kuat yang memiliki dampak besar dan pengaruh pada desain dan operasional TPA. Kualitas air lindi sangat bervariasi tergantung dari kompsisi sampah, umur sampah, iklim, serta hidrogeologinya (Keenan, 1984). Air lindi memiliki karakteristik yang khas, yaitu tingginya kandungan organik, logam, asam, garam terlarut, dan mikro organisme. Karakteristik tersebut menyebabkan air lindi menjadi sangat berbahaya untuk lingkungan dengan potensial kontaminasi melebihi dari beberapa limbah industri.

\subsubsection{Karakteristik Air Lindi Di Indonesia}

Persoalan utama dalam pengolahan lindi adalah penentuan kualitas desain dari lindi yang akan diolah di Instalasi Pengolah Lindi (IPL). Kualitas desain lindi sangat bergantung pada sampling lindi yang dilakukan. Karakteristik dan kuantitas lindi dipengaruhi oleh beberpa hal antara lain karakteristik dan komposisi sampah, jenis tanah penutup landfill, musim, $\mathrm{pH}$ dan kelembaban, serta umur timbunan (usia landfill).Sehingga dalam pengambilan sampel lindi, beberapa hal yang perlu diperhatikan adalah sebagai berikut:
a. Posisi pengambilan sampel.
b. Waktu pengambilan sampel $\rightarrow$ apakah setelah hujan atau pada saat musim kemarau. 
c. Metode pengambilan sampel (apakah composit atau grab sampling).

Lindi yang berasal dari timbunan sampah yang baru mempunyai nilai BOD dan COD yang sangat tinggi, tetapi semakin lama umur landfill, maka kualitas lindi landfill juga akan menurun. Karakteristik lindi berdasarkan umur landfill dapat dilihat pada Tabel 1.

Tabel 1 : Karakteristik Lindi Berdasarkan Umur Landfill (Annonim, 2012).

\begin{tabular}{|l|c|c|c|}
\hline Parameter & $\begin{array}{c}\text { Landfill } \\
\text { Umur }<2 \text { th } \\
(\mathrm{mg} / \mathrm{L})\end{array}$ & $\begin{array}{c}\text { Tipikal } \\
(\mathrm{mg} / \mathrm{L})\end{array}$ & $\begin{array}{c}\text { Landfill Umur } \\
>10 \text { th } \\
(\mathrm{mg} / \mathrm{L})\end{array}$ \\
\hline $\mathrm{BOD}$ & $\begin{array}{c}2.000- \\
30.000\end{array}$ & 10.000 & $100-200$ \\
\hline $\mathrm{COD}$ & $\begin{array}{c}3.000- \\
60.000\end{array}$ & 18.000 & $100-500$ \\
\hline $\mathrm{pH}$ & $4,5-7,5$ & 6,0 & $6,6-7,5$ \\
\hline $\mathrm{TSS}$ & $200-2.000$ & 500 & $100-400$ \\
\hline $\mathrm{N}-\mathrm{NO}_{2}$ & $5-40$ & 20 & $20-40$ \\
\hline $\mathrm{N}-\mathrm{NO}_{3}$ & $5-40$ & 25 & $5-10$ \\
\hline Alkalinitas & $1.000-$ & 3.000 & $200-1.000$ \\
\hline Sulfat & $50-1000$ & 300 & $20-50$ \\
\hline Kalsium & $200-3.000$ & 1.000 & $100-400$ \\
\hline Klorida & $200-2.500$ & 500 & $100-400$ \\
\hline Natrium & $200-2.500$ & 500 & $100-400$ \\
\hline Besi Total & $50-1.200$ & 60 & $20-200$ \\
\hline
\end{tabular}

Secara umum, lindi memiliki karakteristik antara lain adalah:

- Konsentrasi BOD dan COD tinggi diawal.

- Memiliki kandungan nitrogen yang tinggi.

- Daya hantar tinggi, hal tersebut dikarenakan banyaknya mineral yang dilarutkan oleh aliran lindi, sehingga daya hantarnya menjadi tinggi.

- Kandungan logam berat yang kadang tinggi, hal tersebut dikarenakan $\mathrm{pH}$ lindi yang asam dapat melarutkan logam berat yang tercampur pada sampah yang masuk ke TPA

- Memilki pH netral sampai asam.

- Warna yang sulit dihilangkan (coklat muda sampai hitam).

\subsubsection{Kondisi Umum Instalasi Pengolahan Lindi Di Indonesia}

Instalasi pengolahan lindi (leachate) yang ada di TPA - TPA di Indonesia pada umumnya tidak atau belum beroperasi sesuai dengan kriteria teknis yang ada. Beberapa hal yang menyebabkan kurang optimalnya operasi IPL di TPA adalah (Annonim, 2012) :

a. Terbatasnya dana yang dialokasikan untuk pengoperasian dan pemeliharaan IPL di TPA.
Pada umumnya alokasi dana untuk pengelolaan sampah di TPA sudah sangat kecil, sehingga dana yang dialokasikan untuk O/M IPL semakin kecil lagi. Disisi lain, untuk pengoperasian dan pemeliharaannya, IPL memerlukan biaya yang tidak sedikit.

b. Terbatasnya Sumber Daya Manusia yang kompeten yang dapat mengoperasikan IPL.

Di sebagian besar TPA di Indonesia tidak tersedia operator khusus yang bertugas untuk menjalankan IPL. IPL yang ideal seharusnya dijalankan oleh SDM yang kompeten, karena kebanyakan IPL menggunakan pengolahan secara biologis dimana mikroorganisme perlu kondisi yang spesifik untuk dapat bekerja dengan optimal.

c. Tidak ada kontrol dan monitoring yang baik untuk pengoperasian IPL.

Mayoritas IPL di Indonesia dibiarkan berjalan begitu saja tanpa ada control yang baik, padahal seharusnya sebelum mulai dijalankan, harus dilakukan aklimatisasi selama kurang lebih 3 bulan untuk mendapatkan kondisi mikroorganisme yang optimal.

d. Kurang perhatiannya para pengambil kebijakan pada TPA.

Sampai saat ini, pengelolaan sampah belum menjadi prioritas untuk mendapatkan alokasi dana yang besar di daerah - daerah. Hal tersebut dikarenakan masih rendahnya tingkat kesadaran para pengambil kebijakan untuk pengelolaan sampah pada umumnya dan IPL pada khususnya.

Beberapa pilihan alternatif teknologi pengolahan air lindi yang diterapkan di Indonesia adalah sebagai berikut (Annonim, 2012) :

a. Kolam Anaerobik, Fakultatif, Maturasi dan Biofilter (alternatif 1)

b. Kolam Anaerobik, Fakultatif, Maturasi dan Landtreatment / Wetland (alternatif 2)

c. Anaerobic Baffled Reactor (ABR) dengan Aerated Lagoon (alternatif 3)

d. Proses Koagulasi - Flokulasi, Sedimentasi, Kolam Anaerobik atau ABR (alternatif 4)

e. Proses Koagulasi - Flokulasi, Sedimentasi I, Aerated Lagoon, Sedimentasi II (alternatif 5)

Sebagian besar pengolahan air lindi di Indonesia masih menggunakan sistem kolam karena biaya operasionalnya yang rendah, tetapi memerlukan waktu tinggal yang cukup lama. Untuk kolam anaerobik memerlukan waktu tinggal $20-50$ hari dengan efisiensi penghilangan BOD $50-85 \%$, kolam fakultatif memerlukan waktu tinggal 5 -30 hari dengan efisiensi penghilangan BOD $70-80 \%$, sedangkan kolam matrurasi memerlukan waktu 
tinggal 7-20 hari dengan efisiensi penghilangan BOD 60-89\% (Annonim 1, 2012).

Sebagian besar pengolahan lindi di Indonesia memiliki masalah yang sama, yaitu kuantitas dan kualitas lindi yang berfluktuasi. Disisi lain, dasar untuk dapat merencanakan IPL yang baik adalah beban hidrolis $(Q)$, serta beban organik (BOD, COD) yang stabil. Oleh karena itu, diperlukan pengaturan/penyeimbangan untuk debit dan beban organik yang masuk ke IPL, dikarenakan mikroorganisme yang bekerja di IPL tersebut sangat sensitif dengan perubahan debit dan beban organik yang ekstrim. Salah satu cara untuk mengatur debit dan beban organik tersebut adalah dengan menggunakan kolam stabilisasi serta pintu air sebelum inlet IPL.

Beberapa cara yang dapat dilakukan untuk dapat mengurangi dampak negatif dari lindi adalah:

a. Penggunaan lapisan tanah penutup, baik lapisan tanah penutup harian, antara, dan penutup akhir.

b. Pemakaian lapisan dasar/liner yang sesuai dengan kriteria teknis untuk dapat mencegah infiltrasi leachate ke tanah dan air tanah.

c. Pembangunan sarana pengumpul dan pengolah lindi yang sesuai dengan kriteria teknis, serta pembangunan drainase sekeliling TPA yang sesuai dengan kriteria teknis untuk dapat mengurangi jumlah limpasan air hujan yang masuk ke dalam TPA.

d. Melakukan resirkulasi lindi.

\subsection{Teknologi Pengolahan Air Limbah}

Air limbah mempunyai beberapa jenis dan karakteristik tergantung dari mana air limbah tersebut berasal. Dalam menentukan teknologi pengolahan air limbah harus didasarkan kepada karakteristik air limbah yang akan diolah. Pada prinsipnya pengolahan air limbah adalah untuk menetralkan, menguraikan dan mengambil polutan yang ada dalam air limbah sehingga air limbah tersebut dapat dibuang ke lingkungan sesuai peraturan baku mutu yang berlaku. Berdasarkan karakteristik air limbah yang akan diolah, secara garis ada dua jenis teknologi pengolahan air limbah yaitu:

a. Teknologi pengolahan air limbah secara fisika kimia,

b. Teknologi pengolahan air limbah secara biologis.

\subsubsection{Teknologi Pengolahan Secara Fisika Kimia}

Proses kimia-fisika umumnya dipakai untuk mengolah limbah-limbah anorganik seperti air limbah industri pertambangan, pelapisan logam atau pemurnian logam. Proses ini lebih banyak memanfaatkan perbedaan sifat-sifat fisik yang dimiliki oleh polutan dalam air limbah, seperti perbedaan berat jenis, ukuran partikel, dan titik didih. Beberapa contoh proses Kimia- fisika dalam pengolahan limbah adalah proses netralisasi, pengendapan, penyaringan dan penguapan. Pada proses netralisasi dan pengendapan diperlukan penambahan bahan kimia koagulan (penggumpal) dan flokulan (pembentuk flok) yang bertujuan untuk membantu mengikat dan mengendapkan partikelpartikel padat yang tersuspensi dalam air limbah.

Proses kimia fisika ini kelebihannya adalah dapat berlangsung dalam waktu yang singkat sehingga unit instalasi pengolahan air limbah (IPAL) yang diperlukan kecil. Sedangkan kelemahan dari proses ini diantaranya adalah hanya bersifat memindahkan polutan sehingga kalau pengelolaan hasil samping (sludge/endapan) tidak bagus maka akan dapat menimbulkan masalah baru.

\subsubsection{Teknologi Pengolahan Secara Biologis}

Di dalam proses pengolahan air limbah secara biologis, pada hakekatnya adalah memanfaatkan mikroorganisme (bakteria) yang mempunyai kemampuan untuk menguraikan senyawa-senyawa polutan tertentu di dalam suatu reaktor biologis yang dikondisikan. Di dalam proses pertumbuhan dan perkembang-biakan mikroorganisma diperlukan sumber energi, karbon serta elemen anorganik atau nutrien misalnya nitrogen, phospor, sulfur, natrium, kalsium dan magnesium. Dalam proses pengolahan air limbah, sumber energi karbon dan nutrien ini diserap dari polutan yang ada dalam air limbah.

Berdasarkan kebutuhan oksigen, bakteri untuk pengolahan air limbah digolongkan menjadi 3 (tiga) jenis yaitu :

a. Bakteri Aerob Mutlak : yakni bakteri yang tidak dapat hidup dan menguraikan polutan air limbah jika tanpa oksigen di lingkungannya.

b. Bakteria Fakultatif Aerob : yakni bakteri yang dapat tumbuh dan bekerja menguraikan polutan air limbah tanpa oksigen, tetapi pertumbuhannya akan lebih cepat bila terdapat oksigen di lingkungannya.

c. Bakteria Anaerob Mutlak : yakni bakteria yang tidak dapat hidup dan bekerja menguraikan polutan air limbah jika terdapat oksigen di lingkungannya.

Dengan demikian berdasarkan penggolongan dari jenis bakteri yang digunakan, maka teknologi proses IPAL biologis dibagi menjadi dua yaitu teknologi proses anaerob dan teknologi proses Aerob. 


\subsubsection{Proses Biologis Aerob}

Pada proses pengolahan air limbah dengan bakteri aerob, polutan organik, senyawa kimia lain seperti sulfida dan amonia akan diuraikan menjadi senyawa yang stabil dan aman terhadap lingkungan. Proses pengurian secara aerob ini adalah sebagai berikut:

Reaksi Penguraian Organik :

$$
\begin{array}{r}
\text { Oksigen }\left(\mathrm{O}_{2}\right) \\
\text { Senyawa Polutan organik } \underset{\text { Heterotropik }}{\rightarrow} \quad \mathrm{CO}_{2}+\mathrm{H}_{2} \mathrm{O} \\
+\mathrm{NH}_{4}+\text { Biomasa }
\end{array}
$$

Reaksi Nitrifikasi :

$$
\mathrm{NH}_{4}^{+}+1,5 \mathrm{O}_{2} \rightarrow \mathrm{NO}_{2}^{-}+2 \mathrm{H}^{+}+\mathrm{H}_{2} \mathrm{O}
$$$$
\mathrm{NO}_{2}^{-}+0,5 \mathrm{O}_{2} \rightarrow \mathrm{NO}_{3}^{-}
$$

Reaksi Oksidasi Sulfur :

$\mathrm{S}^{2-}+1 / 2 \mathrm{O}_{2} \quad+2 \mathrm{H}^{+} \rightarrow \mathrm{S}^{0}+\mathrm{H}_{2} \mathrm{O}$

$2 \mathrm{~S}+3 \mathrm{O}_{2}+2 \mathrm{H}_{2} \mathrm{O} \rightarrow 2 \mathrm{H}_{2} \mathrm{SO}_{4}$

Dari reaksi reaksi kimia tersebut diatas, oksigen diperlukan untuk menguraikan polutan dan besarnya oksigen yang diperlukan sebanding dengan jumlah organik, sulfida dan amonia yang ada dalam air limbah. Dalam reaksi 1 diatas terllihat kalau organik diuraikan diantaranya menjadi biomasa. Biomasa ini akan dibuang sebagai sisa lumpur yang perlu penanganan lebih lanjut. Kelebihan dari proses aerobik adalah reaksinya berlangsung lebih cepat dibanding proses anaerobik dan dapat mendegradasi polutan organik sampai tingkat konsentrasi yang sangat rendah. Selain kelebihan, ada beberapa kelemahan proses pengolahan air limbah secara aerobik diantaranya:

- Perlu banyak energi untuk suplai oksigen kedalam reaktor pengolah air limbah, biaya operasional tinggi

- Timbul lumpur yang perlu penanganan lebih lanjut. Biaya yang diperlukan untuk penanganan lumpur cukup mahal

- Kurang efektif diaplikasikan untuk air limbah dengan konsentrasi polutan tinggi (BOD diatas $3000 \mathrm{mg} / \mathrm{l}$ )

Dalam aplikasinya di IPAL, proses pengolahan biologi aerobik dapat dilakukan dengan menempatkan atau melengketkan bakteri pada suatu media yang dikenal dengan istilah biakan melekat dan dapat dilakukan dengan mencampurkan bakteri ke dalam air limbah tanpa media yang dikenal dengan biakan tersuspensi.

Efisiensi proses IPAL biologis sangatlah ditentukan oleh jumlah bakteri yang bekerja mendegradasi polutan dalam air limbah. Pada proses biakan melekat, jumlah bakteri dikontrol melalui media. Apabila menginginkan jumlah bakteri yang banyak, maka luas permukaan media dipilih sebesar mungkin. Pada proses biakan tersuspensi, jumlah bakteri dikontrol dengan memantau dan selalu mengukur konsentrasi padatan tersuspensi dalam air limbah sehingga perlu pemantauan yang rutin.

\subsubsection{Proses Anaerob}

Proses biologi anaerob adalah cara pengolahan limbah yang sudah cukup lama dikenal dan ekonomis. Pada awal tahun 1900 proses ini sudah diaplikasikan di Inggris untuk mengolah organic sludge (lumpur organik) yang berasal dari kolam pengendap pada unit pengolahan limbah cair domestik. Selanjutnya proses ini dikembangkan untuk mengolah berbagai jenis limbah industri, khususnya yang mempunyai kadar pencemar organik tinggi.

Pada proses anaerob diperoleh hasil gas metan melalui beberapa tahapan. Pada prosesnya hampir semua polimer organik dapat diuraikan menjadi senyawa karbon tunggal. Tahap penguraian ini meliputi tahap pembentukan asam (acidification) dan tahap pembentukan gas metan (gasification). Proses asidifikasi dilakukan oleh kelompok bakteri acidogenik yang menghidrolisa senyawa-senyawa polimer dan mengkonversinya menjadi asam-asam organik yang merupakan hasil antara. Kemudian bkteri metanogenik pada tahap gasifikasi akan mengubah hasil - hasil antara ini menjadi metan sebagai produk akhir(Polprasert, 1989).

Kedua proses ini berlangsung secara sinambung, secara garis besar, mekanisme penguraian ini seperti terlihat pada Gambar 1.

Reaksi yang terjadi pada proses penguraian polutan organik dalam air limbah dapat diuraikan lebih rinci sebagai berikut :

a. Hidrolisa dan pembentukan asam (hydrolysis \& acidogenesis).

Polutan-polutan organik komplek seperti lemak, protein dan karbohidrat pada kondisi anaerob akan dihidrolisa oleh enzim hydrolaseseperti lipase, protease dan cellulase yang dihasilkan bakteri pada tahap pertama. Hasil hidrolisa polimer-polimer diatas adalah monomer seperti manosakarida, asam amino, peptida dan gliserin. Selanjutnya monomer-monomer ini akan diuraikan menjadi asam-asam lemak (lower fatty acids) dan gas hidrogen(Archer dan Kirsop, 1991; Barnes dan Fitzgerald, 1987; Sahm, 1984; Sterritt dan Lester, 1988; Zeikus, 1980), 


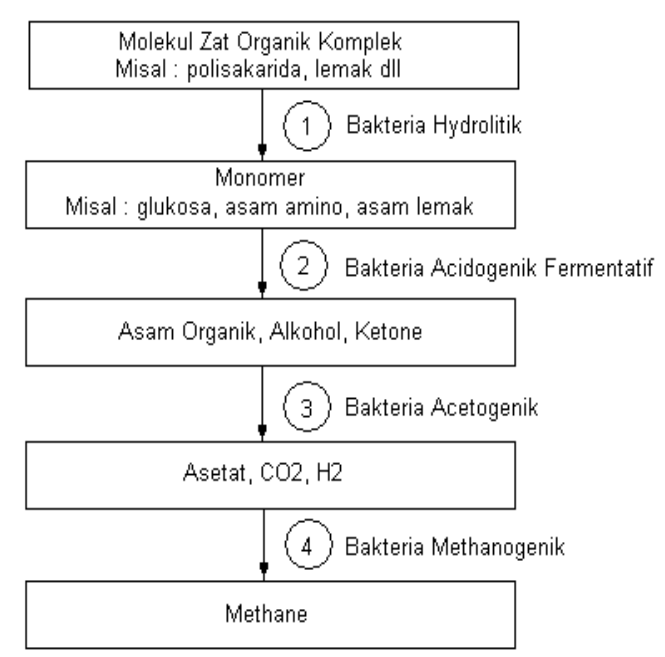

Gambar 1 : Mekanisme Penguraian Polutan Organik Pada Proses Biologi Anaerobik.

Dekomposisi lemak :

$$
\begin{aligned}
& \text { Lipase } \\
& \underset{\text { Lemak }}{\mathrm{C}_{3} \mathrm{H}_{5}(\mathrm{RCOO})_{3}+3 \mathrm{H}_{2} \mathrm{O} \rightarrow 3 \mathrm{RCOOH}+\mathrm{C}_{3} \mathrm{H}_{5}(\mathrm{OH})_{3}} \rightarrow \text { Asam lemak Gliserol }
\end{aligned}
$$

Dekomposisi protein :

\section{Protease}

Protein Asam amino

$$
\begin{aligned}
& \mathrm{RCHNH} \mathrm{H}_{2} \mathrm{COOH}+\mathrm{H}_{2} \rightarrow \mathrm{RCH}_{2} \mathrm{COOH}+\mathrm{NH}_{3} \\
& \text { Asam amino Asam Lemak }
\end{aligned}
$$

Dekomposisi karbohidrat :

$$
\underset{\text { Glukosa }}{\mathrm{C}_{6} \mathrm{H}_{12} \mathrm{O}_{6}} \rightarrow \underset{\text { Asam Butirat }}{\mathrm{CH}_{3} \mathrm{CH}_{2} \mathrm{CH}_{2} \mathrm{COOH}+2 \mathrm{H}_{2}}+2 \mathrm{CO}_{2}
$$$$
\begin{array}{r}
\text { Cellulases } \\
\text { SelulosaGlukosa } \\
\hline
\end{array}
$$

b. Pembentukan asam asetat dan hidrogen (acetogenesis \& dehydrogenation)

Meskipun sejumlah asam asetat dan $\mathrm{H}_{2}$ dihasilkan dari penguraian monosakarida dan asamasam amino pada tahap acidogesis, namun sebagian besar diproduksi dari penguraian asam-asam lemak yang mempunyai gugus karbon lebih tinggi melalui tahap acetogenesis dan dehydrogenation, seperti:

Dekomposisi asam propionat dilakukan oleh Syntrophobacter Wolinii.

$$
\begin{aligned}
& \mathrm{CH}_{3} \mathrm{CH}_{2} \mathrm{COOH}+3 \mathrm{H}_{2} \mathrm{O} \rightarrow \mathrm{CH}_{3} \mathrm{COOH}+\mathrm{H}_{2} \mathrm{CO}_{3} \\
& \text { Asam Propionat Asam Asetat } \\
& +3 \mathrm{H}_{2}
\end{aligned}
$$

Dekomposisi asam butirat oleh Syntrophomonas Wolfei.

$$
\underset{\text { Asam Butrirat }}{\mathrm{CH}_{3} \mathrm{CH}_{2} \mathrm{CH}_{2} \mathrm{COOH}+2 \mathrm{H}_{2} \mathrm{O}} \underset{\text { Asam Asetat }}{\rightarrow} \underset{2 \mathrm{CH}_{3} \mathrm{COOH}+2 \mathrm{H}_{2}}{\rightarrow}
$$

Dekomosisi asam laktat oleh Clostridium Formicoaceticum.

$\mathrm{CH}_{3} \mathrm{CHOHCOOH}+2 \mathrm{H}_{2} \mathrm{O} \rightarrow \mathrm{CH}_{3} \mathrm{COOH}+\mathrm{H}_{2} \mathrm{CO}_{3}$ Asam Laktat

$$
+2 \mathrm{H}_{2} \mathrm{O}
$$

ReaksiH ${ }_{2}$ dengan $\mathrm{CO}_{2}$ oleh ClostridiumAceticumdanAcetobacterium Woodii.

$4 \mathrm{H}_{2}+2 \mathrm{CO}_{2} \rightarrow \mathrm{CH}_{3} \mathrm{COOH}+2 \mathrm{H}_{2} \mathrm{O}$

c. Tahap pembentukan gas metan (methanogenesis)

Sumber utama pembentukan gas metan adalah asam asetat, $\mathrm{H}_{2}$ dan $\mathrm{CO}_{2}$. Disamping itu juga bisa dihasilkan dari konversi asam formiat dan metanol.

$\underset{\text { Asam Asetat }}{\mathrm{CH}_{3} \mathrm{COOH}} \rightarrow \mathrm{CH}_{4}+\mathrm{CO}_{2}$

$\mathrm{CO}_{2}+4 \mathrm{H}_{2} \rightarrow \mathrm{CH}_{4}+2 \mathrm{H}_{2} \mathrm{O}$

$\mathrm{HCOOH} \rightarrow 0,25 \mathrm{CH}_{4}+0,75 \mathrm{CO}_{2}+0,5 \mathrm{H}_{2} \mathrm{O}$

$\underset{\text { Metanol }}{\mathrm{CH}_{3} \mathrm{OH}} \rightarrow 0,75 \mathrm{CH}_{4}+0,25 \mathrm{CO}_{2}+0,5 \mathrm{H}_{2} \mathrm{O}$

Secara fundamentaldiketahui bahwa, jumlah bakteri sangat mempengaruhi kecepatan reaksi penguraian polutan diatas. Disamping konsentrasi bakteri, penambahan nutrisi tertentu seperti senyawa nitrogen dan phosfat dapat mempercepat proses degradasi. Disamping itu, pemberian mineral anorganik seperti $\mathrm{Co}^{+2}, \mathrm{Ni}^{+2}$ dan $\mathrm{Fe}^{+3}$ dalam jumlah mikrodapat merangsang aktivitas mikroba dan meningkatkan effisiensi pengolahan.

Disamping mempercepat, ada beberapa senyawa kimia yang bersifat racun terhadap mikroba anaerobik, sehingga perlu dihilangkan pada tahap pretearment. Bahan kimia yang dapat mengganggu proses anaerobik adalah senyawa-senyawa sulfur, sianida dan logam-logam berat $\left(\mathrm{Cr}^{+6}, \mathrm{Hg}^{+2}, \mathrm{Cu}^{+2}\right)$.

Dibandingkan dengan proses biologis aerobik, proses anaerobik mempunyai beberapa keunggulan, antara lain :

- Hemat energi.Pada pengolahan anaerobik, proses penguraian polutan-polutan organik oleh mikroba berlansung pada kondisi tanpaudara, sehingga tidak diperlukan energi untuk mensupply udara seperti halnya pada proses aerobik. 
- Menghasilkan biogas (gas metan). Salah satu produk akhir penguraian polutan organik adalah gas metan $\left(\mathrm{CH}_{4}\right)$ yang dapat dimanfaatkan sebagai bahan bakar gasa yang kaya energi, seperti pada generatorpembangkit listrik atau pada boiler pembangkit uap. Nilai panas $1 \mathrm{~m}^{3}$ gas $\mathrm{CH}_{4}$ setara dengan $8.550 \mathrm{kcal}$.

- Mampu mengolah limbah organik berkonsentrasi tinggi (BOD sampai 80,000 $\mathrm{mg} / \mathrm{l})$.

- $\quad$ Surplus sludge yang merupakan surplus bakteri lebih sedikit dan dengan mudah dapat dimanfaatkan sebagai pupuk organik.

Disamping hal-hal positif, proses anaerobik juga mempunyai kelemahan, seperti :

- Reaksi penguraian polutan lambat.

- Sangat sensitif terhadap udara, perubahan temperatur dan fluktuasi beban.

- Kurang effektif untuk mengolah limbah berkonsentrasi rendah (BODdibawah 3.000 $\mathrm{mg} / \mathrm{l})$.

Seperti pada proses biologis aerob, proses anaerob pada aplikasinya dapat dilakukan dengan sistem biakan melekat ataupun biakan tersuspensi.

\subsubsection{Proses Denitrifikasi}

Ada beberapa proses yang bisa diterapkan untuk denitrifikasi yaitu proses kimia fisika seperti penukar ion, pemisahan dengan membran dan proses biologis dengan menggunakan bakteri heterotroph dan autotroph. Dahab 1988, melakukan kajian berbagai proses denitrifikasi tersebut diatas untuk air limbah dan menyimpulkan kalau sistem biologis adalah yang paling ekonomis dan layak.

Denitrifikasi dengan menggunakan sistem biologis untuk air limbah yang cukup kandungan BOD (Biological Oxygen Demand)/ $\mathrm{N}$ nya seperti untuk limbah domestik dan limbah industri, biasanya menggunakan mikroba heterotroph. Kandungan organik (sebagai BOD) yang ada di dalam air limbah digunakan sebagai donor hidrogen pada reaksi denitrifikasi heterotroph. Reaksi denitrifikasi yang terjadi pada pengolahan limbah dengan mikroba heterotroph adalah sebagai berikut:

$$
12 \mathrm{NO}_{3}^{-}+5 \mathrm{C}_{2} \mathrm{H}_{5} \mathrm{OH} \rightarrow 6 \mathrm{~N}_{2}+10 \mathrm{CO}_{2}+9 \mathrm{H}_{2} \mathrm{O}+12 \mathrm{OH}^{-}
$$

Pada proses konvensional, denitrifikasi air limbah yang mempunyai kandungan BOD/N rendah atau kandungan senyawa nitrogennya relatif tinggi dilakukan dengan menggunakan mikroba heterotroph, yaitu dengan menambahkan bahan organik sebagai donor hidrogen ke dalam air limbah. Akibatnya biaya pengolahan limbah menjadi besar. Disamping itu, untuk meningkatkan efisiensi reaksi denitrifikasi, penambahan bahan organik tersebut dilakukan berlebih. Agar supaya bahan organik yang tidak bereaksi atau yang tersisa dalam air limbah setelah proses denitrifikasi tidak menimbulkan pencemaran lingkungan, perlu dilakukan proses biodegradasi lagi sebelum limbah dibuang ke perairan. Dengan demikian denitrifikasi secara konvensional dengan mikroba heterotroph disamping perlu biaya besar juga prosesnya menjadi rumit karena perlu banyak unit-unit pengolahan. Untuk air limbah nitrat yang mengandung BOD rendah, penulis mengusulkan alternartif lain yaitu dengan menggunakan mikroba autotroph.

Mikroba autotroph adalah jenis mikroba atau bakteri yang dalam melakukan aktifitas maupun pertumbuhannya tidak memerlukan bahan organik tapi cukup dengan menggunakan bahan anorganik dan sumber karbon dari $\mathrm{CO}_{2}$. Salah satu jenis mikroba ini adalah Thiobacillus denitrificans yang dapat mereduksi nitrat menjadi nitrogen gas dengan menggunakan senyawa belerang tereduksi seperti batuan belerang, thiosulfat, ferry sulfat maupun hidrogen sulfida sebagai donor elektron. Senyawa belerang ini pada akhir reaksi denitrifikasi akan teroksidasi menjadi sulfat dengan reaksi sebagai berikut:

$1.114 \mathrm{~S}^{\circ}+\mathrm{NO}_{3}^{-}+0.699 \mathrm{H}_{2} \mathrm{O}+0.337 \mathrm{CO}_{2}+$ $0.0842 \mathrm{HCO}_{3}^{-}+0.0842 \mathrm{NH}_{4}^{+} \rightarrow 1.114 \mathrm{SO}_{4}{ }^{2-}+$ $0.5 \mathrm{~N}_{2}+1.228 \mathrm{H}^{+}+0.0842 \mathrm{C}_{5} \mathrm{H}_{7} \mathrm{O}_{2} \mathrm{~N}$ (biomass)

$0.844 \mathrm{~S}_{2} \mathrm{O}_{3}{ }^{2-}+\mathrm{NO}_{3}^{-}+0.434 \mathrm{H}_{2} \mathrm{O}+0.347 \mathrm{CO}_{2}+$ $0.0865 \mathrm{HCO}_{3}{ }^{-}+0.0865 \mathrm{NH}_{4}^{+} \rightarrow 1.689 \mathrm{SO}_{4}{ }^{2-}+$ $0.5 \mathrm{~N}_{2}+0.697 \mathrm{H}^{+}+0.0865 \mathrm{C}_{5} \mathrm{H}_{7} \mathrm{O}_{2} \mathrm{~N}$ (biomass)

$0.422 \mathrm{H}_{2} \mathrm{~S}+\mathrm{NO}_{3}^{-}+0.422 \mathrm{HS}^{-}+0.346 \mathrm{CO}_{2}+$ $0.0865 \mathrm{HCO}_{3}^{-}+0.0865 \mathrm{NH}_{4}^{+} \rightarrow 0.844 \mathrm{SO}_{4}{ }^{2-}+$ $0.5 \mathrm{~N}_{2}+0.288 \mathrm{H}^{+}+0.403 \mathrm{H}_{2} \mathrm{O}+0.0865 \mathrm{C}_{5} \mathrm{H}_{7} \mathrm{O}_{2} \mathrm{~N}$ (biomass)

Kelebihan dari proses denitrifikasi dengan mikroba autotroph yaitu:

- Tidak memerlukan penambahan bahan organik sehingga biaya pengolahan limbah dapat ditekan.

- Mempunyai sifat yang lambat dalam pertumbuhan dibanding bakteri heterotroph sehingga bila diterapkan dalam pengolahan limbah sistem biologis tidak akan banyak menghasilkan sisa lumpur. Sisa-sisa lumpur merupakan salah satu kendala dalam penanganan dan pengolahan limbah sistem biologis karena untuk mengolahnya perlu biaya yang cukup besar.

- Tidak menimbulkan polusi sampingan oleh bahan organik yang tidak terolah. 
- $\quad$ Bisa diterapkan dengan sistem yang sederhana yaitu dengan reaktor bahan isian batu belerang dan batu kapur.

\subsection{Mekanisme Penguraian Senyawa Polutan Pada Proses Biofilter}

Di dalam reaktor biofilter, mikroorganisme tumbuh melapisi keseluruhan permukaan media. Pada saat operasi, air yang mengandung senyawa polutan mengalir melalui celah media dan kontak langsung dengan lapisan massa mikroba (biofilm). Biofilm yang terbentuk pada lapisan atas media dinamakan zoogleal film, yang terdiri dari bakteri, fungi, alga, protozoa (Eighmy,1983 di dalam Bitton 1994). Metcalf dan Edy (1991) mengatakan bahwa sel bakterilah yang paling berperan dan banyak dipakai secara luas di dalam proses pengolahan air buangan, sehingga struktur sel mikroorganisme lainnya dapat dianggap sama dengan bakteri.

Proses yang terjadi pada pembentukan biofilm pada air limbah sama dengan yang terjadi di lingkungan alami. Mikroorganisme yang ada pada biofilm akan mendegradasi senyawa organik yang ada di dalam air. Lapisan biofilm yang semakin tebal akan mengakibatkan berkurangnya difusi oksigen ke lapisan biofilm yang dibawahnya, hal ini mengakibatkan terciptanya lingkungan anaerob pada lapisan biofilm bagian atas (Metcalf and Eddy, 1991).

Mekanisme yang terjadi pada reaktor melekat diam terendam adalah (Lim dan Grady, 1980) :

- Transportasi dan adsopsi zat organik dan nutrien dari fasa liquid ke fasa biofilm

- Transportasi mikroorganisme dari fasa liquid ke fasa biofilm

- Adsorpsi mikroorganisme yang terjadi dalam lapisan biofilm

- Reaksi metabolisme mikroorganisme yang terjadi dalam lapisan biofilm, memungkinkan terjadinya mekanisme pertumbuhan, pemeliharaan, kematian dan lysis sel.

- Attachment dari sel, yaitu pada saat lapisan biofilm mulai terbentuk dan terakumulasi secara kontinu dan gradual pada lapisan biofilm.

- Mekanisme pelepasan (detachment biofilm) dan produk lainnya (by product).

Pertumbuhan mikrooorganisme akan terus berlangsung pada lapisan biofilm yang sudah terbentuk sehingga ketebalan biofilm bertambah. Difusi makanan dan $\mathrm{O}_{2}$ akan berlangsung sampai ketebalan maksimum. Pada kondisi ini, makanan dan $\mathrm{O}_{2}$ tidak mampu lagi mencapai permukaan padat atau bagian terjauh dari fase cair. $\mathrm{Hal}$ ini menyebabkan lapisan biomassa akan terbagi menjadi dua bagian, yaitu lapisan aerob dan lapisan anaerob. Jika lapisan biofilm bertambah tebal maka daya lekat mikroorganisme terhadap media penyangga tidak akan kuat menahan gaya berat lapisan biofilm dan akan terjadi pengelupasan lapisan biomassa. Koloni mikroorganisme yang baru sebagai proses pembentukan lapisan biofilm akan terbentuk pada bagian yang terkelupas ini. Pengelupasan dapat juga terjadi karena pengikisan berlebihan cairan yang mengalir melalui biofilm. Mekanisme proses yang terjadi pada sistem biofilter secara sederhana dapat ditunjukkan seperti pada Gambar 2.

Gambar 2 tersebut menunjukkan suatu sistem biofilm yang terdiri dari medium penyangga, lapisan biofilm yang melekat pada medium, lapisan alir limbah dan lapisan udara yang terletak diluar. Senyawa polutan yang ada di dalam air limbah misalnya senyawa organik (BOD, COD), amoniak, phospor dan lainnya akan terdifusi ke dalam lapisan atau film biologis yang melekat pada permukaan medium. Pada saat yang bersamaan dengan menggunakan oksigen yang terlarut di dalam air limbah senyawa polutan tersebut akan diuraikan oleh mikroorganisme yang ada di dalam lapisan biofilm dan energi yang dihasilkan akan diubah menjadi biomasa. Suplai oksigen pada lapisan biofilm dapat dilakukan dengan beberapa cara misalnya dengan cara kontak dengan udara luar dengan aliran balik udara, atau dengan menggunakan blower udara atau pompa sirkulasi.

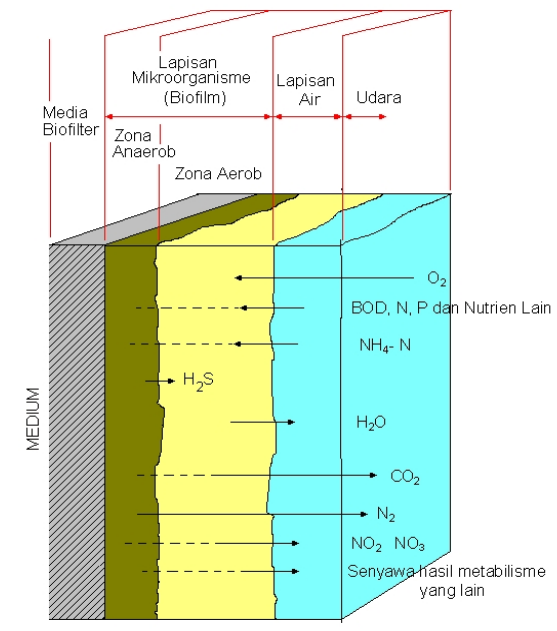

Gambar 2 : Mekanisme Proses Metabolisme Di Dalam Sistem Biofilm. (Disesuaikan dari Viessman and Hamer, (1985), Hikami, (1992)).

Jika lapiasan mikrobiologis cukup tebal, maka pada bagian luar lapisan mikrobiologis akan berada dalam kondisi aerobik sedangkan pada bagian dalam biofilm yang melekat pada medium akan berada dalam kondisi anaerobik. Pada kondisi anaerobik akan terbentuk gas $\mathrm{H}_{2} \mathrm{~S}$, dan jika konsentrasi oksigen 
terlarut cukup besar maka gas $\mathrm{H}_{2} \mathrm{~S}$ yang terbentuk tersebut akan diubah menjadi sulfat $\left(\mathrm{SO}_{4}\right)$ oleh bakteri sulfat yang ada di dalam biofilm.

Selain itu pada zona aerobik nitrogenamoniak akan diubah menjadi nitrit dan nitrat dan selanjutnya pada zona anaerobik nitrat yang terbentuk mengalami proses denitrifikasi menjadi gas nitrogen. Oleh karena di dalam sistem biofilm terjadi kondisi anaerobik dan aerobik pada saat yang bersamaan maka dengan sistem tersebut proses penghilangan senyawa nitrogen menjadi lebih mudah.

Pada proses aerobik efisiensi akan menurun dengan bertambahnya ketebalan lapisan biofilm dan semakin tebalnya lapisan anaerob. Walaupun lapisan biomassa mempunyai ketebalan beberapa milimeter tetapi hanya lapisan luar setebal 0,05 - $15 \mathrm{~mm}$ yang merupakan lapisan aerob. Hasil penelitian yang telah dilakukan sebelumnya menegaskan bahwa penghilangan substrat oleh lapisan mikroba akan bertambah secara linier dengan bertambahnya ketebalan film sampai dengan ketebalan maksimum, dan penghilangan tetap konstan dengan bertambahnya ketebalan lebih lanjut (Winkler,1981). Ketebalan lapisan aerob diperkirakan antara 0,06-2 $\mathrm{mm}$, sedangkan ketebalan kritis berkisar antara 0,07 - 0,15 mm yang tergantung pada konsentrasi substrat (Winkler, 1981).

Fenomena modeling biofilm umumnya diasumsikan sebagai biofilm homogen dengan ketebalan dan kerapatan masa mikroorganisme yang homogen dan konstan. Hal ini di dalam kenyataannya tidak selalu demikian (Christensen,1988). Umumnya observasi dimana waktu dikaitkan dengan penambahan luas permukaan biofilm dan di beberapa kasus meskipun bentuk media dikembangkan. Sampai saat sedikit sekali informasi tentang faktor yang dapat mempengaruhi bentuk biofilm seperti kerapatan dari biomasa.

Kinner (1983) menggambarkan model reaksi biokimia (reaksi redoks) yang terjadi di dalam biofilm sebagai fungsi beban substrat (Arvin and Harremoes, 1990), seperti pada Gambar 3. Gambar yang paling atas adalah menggambarkan reaksi di dalam biofilm di dalam kondisi yang paling kompleks dimana beban substrat organik tinggi.

Di dalam lapisan biofilm tersebut terdapat empat zona atau lapisan yang menggambarkan kondisi reaksi redoks yang ada di dalam biofilm, yaitu zona aerobik, zona micro-aerophilic, zona fakultatif anaerobik serta zona anaerobik.

Lapisan yang paling luar adalah zona aerobik dimana terjadi reaksi oksidasi heterotrophik terhadap zat organik, reaksi nitrifikasi dan oksidasi sulfida. Dibawah lapisan aerobik terdapat lapisan atau zona micro-aerophilic dimana terjadi reaksi denitrifikasi dan reaksi fermentasi zat organik. Dibawah lapisan micro-aerophilic terdapat zona atau lapisan fakultatif anaerobik dimana didalam zona tersebut terjadi reaksi reduksi sulfat dan reaksi fermentasi organik. Lapisan yang paling bawah yang berbatasan dengan media penyangga adalah zona anaerobik dimana terjadi reaksi fermentasi zat organik dan reaksi metanogenesis.

Di dalam tiap lapisan biofilm tersebut terdapat beberapa grup mikroorganisme yang berbeda tergantung dari tingkat kompetisi pertumbuhannya di dalam lapisan biofilm. Selain itu ketebalan lapisan biofilm serta kondisi di dalam lapisan biofilm tergantung dari konsentrasi substrat yang ada di dalam air. Untuk konsentrasi substrat yang rendah misalnya konsentrasi zat organik rendah, maka ketebalan lapisan biofilm pada permukaan media sangat tipis dan zona yang ada di dalam biofilm hanya terdapat zona aerobik dan reaksi yang terjadi didominasi oleh reaksi nitrifikasi. Walaupun prosesnya secara aerobik, ketebalan lapisan atau zona aerobik di dalam biofilm hanya sekitar 0,1-0,2 mm (Viessman and Hamer, 1985).

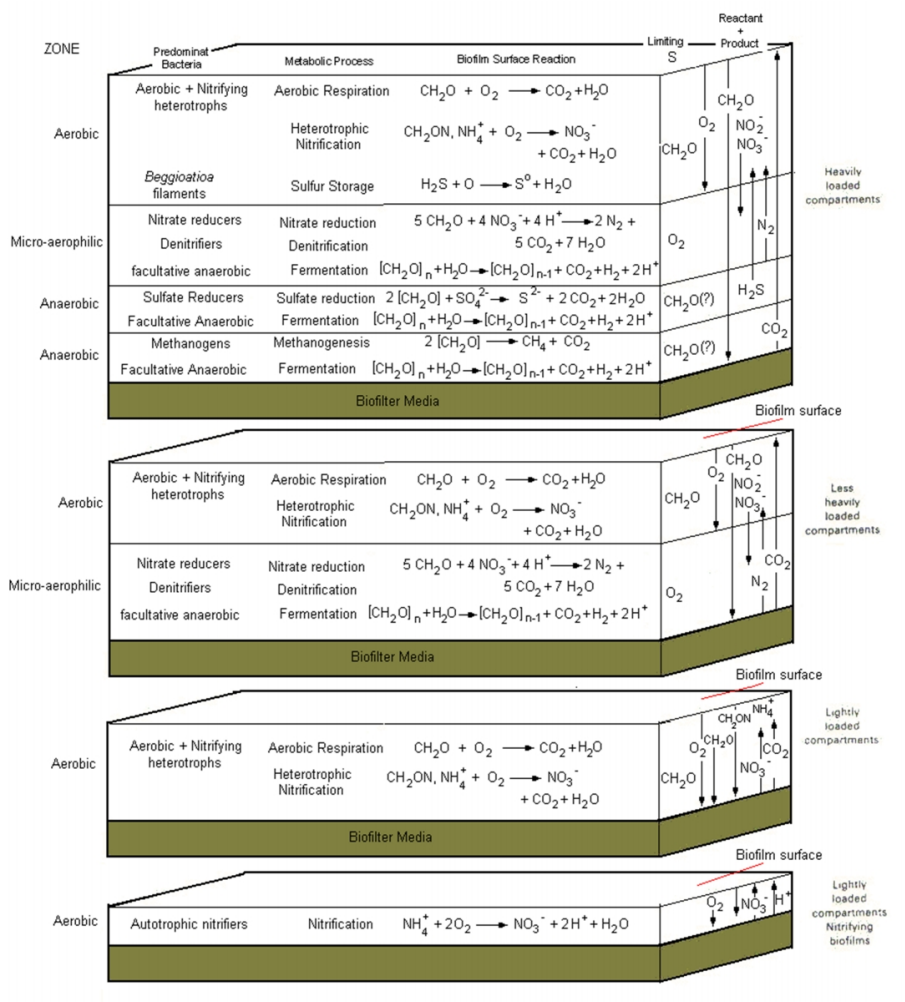

Gambar 3 : Model Reaksi Bokimia di dalam Biofilm dengan Beban Air Limbah yang berbeda (Arvin and Harremoes, 1990).

Beberapa faktor yang dapat mempengaruhi ketebalan biofilm antara lain adalah:

- Pertumbuhan dari biomasa yang aktif akibat dari aliran substrat. 
- Kerusakan biomasa aktif.

- Akumulasi material organik inert akibat dari bakteri yang aktif yang mati.

- Akumulasi polimer dari metabolisme substrat. Polimer dapat dipecah atau didegradasi dengan sangat lambat.

- Penumpukan atau flokulasi dari partikel yang tersuspensi ke dalam biofilm.

- Erosi permukaan biofilm dari partikel-partikel kecil.

- Pelepasan bagian-bagian besar dari biofilm akibat beban hidrolik yang terlalu besar.

Sampai saat ini kemampuan untuk memperkirakan ketebalan biofilm adalah masih sangat terbatas. Sebagai konsekuensinya kontrol ketebalan dalam reaktor biofilm masih berdasarkan pada penelitian murni secara empiris (Arvin and Harremoes, 1990).

\section{MATERIAL DAN METODOLOGI PENELITIAN}

\subsection{Tempat Penelitian}

Penelitian dilakukan di laboratorium Pusat Teknologi Lingkungan, Badan Pengkajian dan Penerapan Teknologi Kawasan Puspiptek Serpong Tangerang Selatan.

\subsection{Material}

\subsubsection{Bahan}

Bahan - bahan yang digunakan dalam penelitian ini adalah:

\section{a. Air Lindi}

Air lindi yang akan diolah adalah air lindi yang berasal dari tempat pembuangan akhir (TPA) Bantar Gebang-Bekasi.

\section{b. Lumpur Biologis}

Lumpur biologis (biological sludge) yang digunakan diperoleh dari proses pembiakan bakteri di dalam reaktor yang telah diisi dengan media sarang tawon sebagai tempat melekatnya mikroba. Proses pembiakan bakteri tersebut dilakukan dengan menggunakan air limbah domestik Gedung Geostek Kawasan Puspiptek Serpong, yang disirkulasikan ke dalam reaktor selama satu minggu, selanjutnya di alirkan air lindi secara bertahap. Proses pembiakan mikroba dilakukan selama satu bulan.

\section{c. Glukosa}

Glukosa digunakan pada tahap aklimatisasi untuk membuat air lindi sintesis pada bioreaktor anaerob maupun aerob.

\section{d. StarBio}

StarBio digunakan sebagai nutrisi mikroba baik mikroba anaerob maupun aerob. Sebelum dimasukkan ke dalam bioreaktor anaerob dan aerob, StarBio tersebut terlebih dahulu dilarutkan dalam air.

\section{e. Batuan Sulfur}

Batuan sulfur digunakan sebagai media penyangga pada reaktor denitrifikasi. Batuan sulfur dalam bioreaktor ini berperan sebagai donor proton $\left(\mathrm{H}^{+}\right)$yang akan bereaksi dengan senyawa nitrat untuk berubah menjadi senyawa antara yaitu nitrit, dan akhirnya menjadi gas nitrogen.

\section{f. Batuan Kapur}

Selain batuan sulfur, dalam bioreaktor denitrifikasi juga diisi dengan batuan kapur digunakan sebagai media penyangga. Batuan kapur berfungsi sebagai pensuplai alkalinity pada cairan air limbah, sehingga menjadikan $\mathrm{pH}$ netral.

g. Bahan - bahan kimia untuk analisa, antara lain:

$\begin{array}{lll}\circ & \mathrm{H}_{2} \mathrm{SO}_{4} & \text { : Analisa COD } \\ \circ & \mathrm{K}_{2} \mathrm{Cr}_{2} \mathrm{O}_{7} & \text { : Analisa COD } \\ \circ & \text { NitraVer } 4 & \text { : Analisa Nitrat } \\ \circ & \text { NitriVer 3 } & \text { : Analisa Nitrit } \\ \circ & \text { SulfaVer 5 } & \text { : Analisa Sulfat } \\ \circ & \text { Ammonia Cyanurate } & \text { : Analisa Amonia } \\ \circ & \text { Ammonia Salicilate } & \text { : Analisa Amonia }\end{array}$

\subsubsection{Peralatan Analisa}

Analisa dilakukan dengan 2 cara, yaitu analisa eksternal yang dilakukan oleh Laboratorium Lingkungan dari pihak luar dan analisa internal atau swapantau yang dilakukan di laboratorium Pusat Teknologi Lingkungan.

Peralatan analisa internal yang digunakan untuk pemantauan lindi adalah spektrofotometer HACH DR2800, dan COD Reactor Hanna Instruments HI 839800.

\subsubsection{Peralatan Proses}

Ada 2 (dua) jenis peralatan proses, yaitu peralatan proses skala pilot plant dan peralatan bench scale yang digunakan dalam penelitian pengolahan air lindi dengan proses biofilter anaerob - aerob dan proses denitrifikasi. Pada dasarnya prinsip kerja kedua peralatan tersebut sama. Yang membedakan hanyalah kapasitas peralatan dalam mengolah limbah lindi.

Peralatan yang digunakan dalam penelitian ini baik bench scale maupun skala pilot plant antara lain adalah: 
a. Bioreaktor Anaerob

Bioreaktor anaerob yang digunakan dalam penelitian ini adalah reaktor bench scale berbentuk rectangular, terbuat dari bahan acrilic dengan dimensi panjang $30 \mathrm{~cm}$, lebar $15 \mathrm{~cm}$, dan tinggi 150 $\mathrm{cm}$. Di dalam reaktor tersebut diisi dengan media biofilter tipe sarang tawon yang berfungsi sebagai media melekatnya mikroba. Dalam penelitian ini digunakan 2 buah bioreaktor anaerob (Gambar 4).
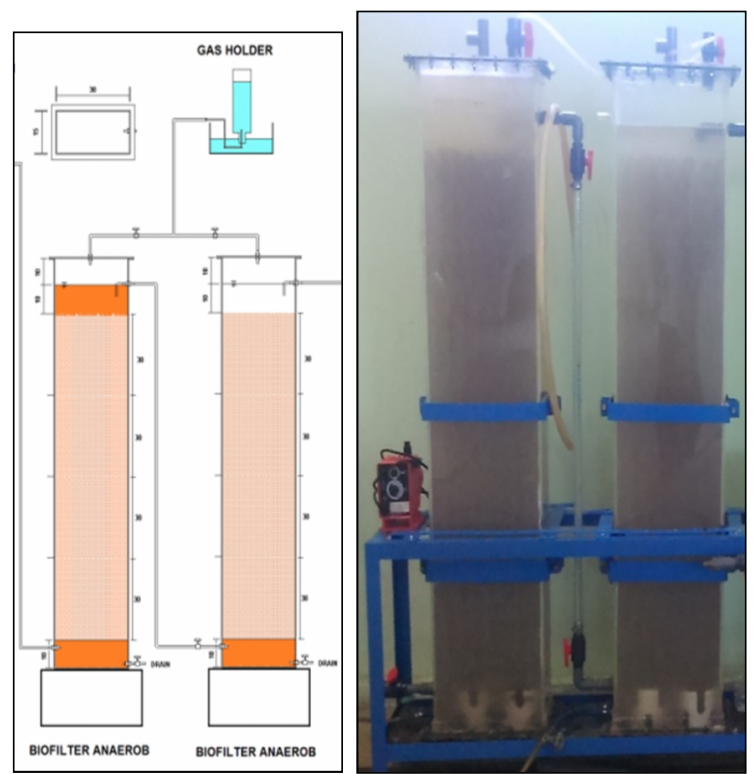

Gambar 4: Bioreaktor Anaerob Bench Scale.

\section{b. Bioreaktor Aerob}

Bioreaktor aerob bench scale yang digunakan dalam penelitian ini berbentuk rectangular dan terbuat dari bahan acrilic. Bioreaktor ini memiliki dimensi panjang $20 \mathrm{~cm}$, lebar $15 \mathrm{~cm}$, dan tinggi 150 $\mathrm{cm}$. Sama seperti bioreaktor anaerob, bioreaktor aerobbench scale juga diisi dengan media biofilter tipe sarang tawon. Kelengkapan lainnya dalam bioreaktor ini adalah blower, dan diffuser yang berfungsi untuk menghembuskan udara (Gambar 5).
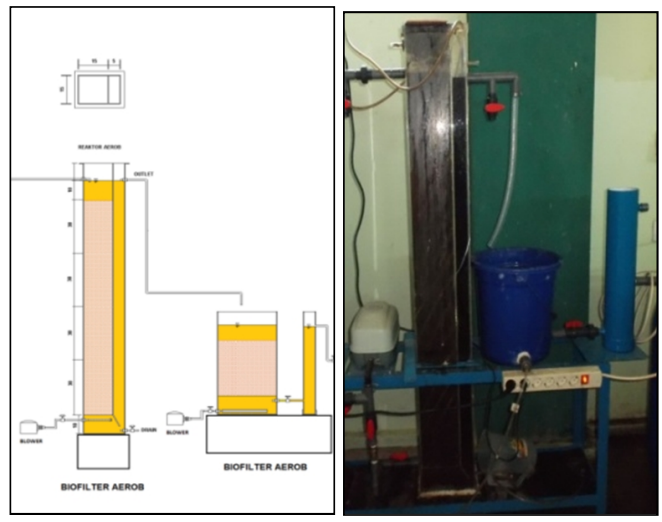

Gambar 5 : Bioreaktor Aerob Bench Scale. c. Bioreaktor Denitrifikasi

Bioreaktor denitrifikasi Bench Scale yang digunakan berukuran 5 liter berbentuk rectangular dan terbuat dari bahan plastik. Dalam bioreaktor ini diisi dengan batuan sulfur dan batuan kapur sebagai media penyangga mikroba (Gambar 6).

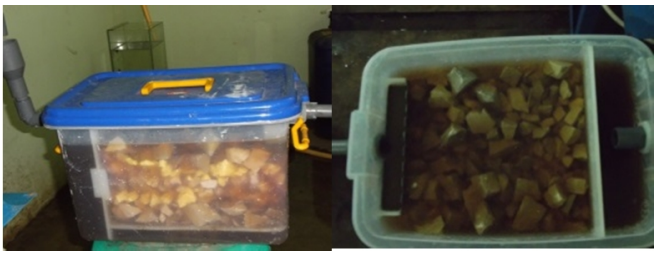

Gambar 6 : Bioreaktor Denitrifikasi Bench Scale.

\subsubsection{Parameter Yang Dianalisa}

Parameter yang dianalisa pada penelitian ini antara lain:

a. COD (chemical Oxigen Demand) adalah jumlah oksigen yang diperlukan untuk mengoksidasi bahan organik yang ada dalam air lindi secara kimiawi. Sebagai oksidatornya digunakan Kalium Permanganat atau Kalium Bikromat.

b. Amonia nitrogen $\left(\mathrm{NH}_{4}-\mathrm{N}\right)$ adalah kandungan nitrogen dalam bentuk amonium yang ada dalam air lindi. Amonia merupakan parameter pencemar yang cukup berat dan efeknya apabila kandungan berlebih akan mematikan biota.

c. Nitrat nitrogen $\left(\mathrm{NO}_{3}-\mathrm{N}\right)$ adalah kandungan nitrogen dalam bentuk nitrat yang ada dalam air lindi. Nitrat merupakan parameter pencemar yang menyebabkan penumpukan nutrien di perairan sehingga dapat menimbulkan alga blooming. Selain itu juga apabila nitrat ini mengkontaminasi air minum, maka akan dapat menyebabkan penyakit "blue baby syndrome".

d. Nitrit nitrogen $\left(\mathrm{NO}_{2}-\mathrm{N}\right)$ adalah kandungan nitrogen dalam bentuk nitrit yang ada dalam air lindi. Efek dari nuitrit adalah sama seperti nitrat. Bahkan dampak dari nitrit lebih berat lagi yaitu apabila bereaksi dengan organik di perairan dapat menimbulkan zat nitrosoamin yang merupakan senyawa penyebab kanker.

e. Total Suspended Solid (TSS) adalah padatan tersuspensi yang ada dalam air limbah. TSS ini juga berhubungan denganjumlah mikroba dalam bak aerasi dan berhubungan dengan kekeruhan.

\subsubsection{Prosedur Analisa}

Prosedur analisa internal untuk semua parameter yang diuji didasarkan pada DR 2800 
Spectrophotometer Procedures Manual dengan nomor katalog DOC022.53.00725 (Annonim-2, 2007). Penelitian dilakukan di laboratorium Pusat Teknologi Lingkungan, Badan Pengkajian dan Penerapan Teknologi Kawasan Puspiptek Serpong, Tangerang Selatan.

\subsubsection{Prosedur Percobaan}

Penelitain dilakukan dengan menggunakan reaktor "Bench Scale" dengan kombinasi proses biofilter anaerob - aerob dengan media isian plastik tipe sarang tawon, dan proses denitrifikasi dengan media isian belerang dan batu kapur. Pertama limbah dipompa kedalam bak pengendap yang bertujuan untuk mengendapkan partikel padatan sebelum masuk kedalam reaktor biologi. Setelah itu air limbah dialirkan ke reaktor biologi anaerob. Pada reaktor ini limbah dikontakkan dengan mikroorganisme yang melekat pada media biofilter dalam kondisi tidak ada udara (anaerob). Kemudian limbah masuk ke dalam reaktor biologi aerob dan selanjutnya dialirkan ke reaktor denitrifikasi.

Diagram proses pengolahan pengolahan air lindi dengan proses biofilter anaerob-aerob dan proses denitrifikasi dengan media isian belerang dan batu kapur dapat dilihat pada Gambar 7. (LAMPIRAN).

\section{HASIL PENELITIAN DAN PEMBAHASAN}

Penelitian air lindi dilakukan kurang lebih selama 3 bulan, dengan menggunakan reaktor bench scale kontinyu proses biologis anaerob, aerob dan denitrifikasi. Pada tahap awal, dilakukan pembibitan mikroba di reaktor biofilter anaerob - aerob. Mikroba yang digunakan untuk proses seeding, diambil dari IPAL Gedung Geostek Serpong. Proses pembiakan bakteri di dalam reaktor dilakukan dengan menggunakan air limbah domestik yang disirkulasikan ke dalam reaktor selama satu minggu, selanjutnya di alirkan air lindi secara bertahap. Proses pembiakan mikroba dilakukan selama satu bulan. Selanjutnya dilakukan penelitian dengan menggunakan air lindi dengan mengatur waktu tinggal di dalam reaktor.

\subsection{Proses Anaerob}

Dalam penelitian ini digunakan 2 buah reaktor anaerob. Masing - masing tangki, diisi dengan media biofilter sarang tawon yang berfungsi sebagai tempat melekatnya mikroba. Untuk tahap ini, air limbah domestik tersebut ditambahkan glukosa yang bertujuan untuk mempercepat tumbuhnya mikroba pada air limbah. Selain glukosa, selama proses aklimatisasi ditambahkan juga StarBio yang berfungsi sebagai nutrisi bagi mikroba. Selanjutnya, penambahan glukosa dan StarBio diganti dengan air lindi. Penambahan dilakukan setiap hari secara bertahap.

Waktu tinggal di dalam masing - masing reaktor anaerob selama 4 hari. Jadi waktu tinggal total di dalam reaktor anaerob adalah selama 8 hari. Dengan waktu tinggal selama 8 hari, efisiensi penurunan COD di reaktor anaerob sebesar 90,16 \%. Dengan konsentrasi COD inlet rata - rata adalah $7847,69 \mathrm{mg} / \mathrm{l}$ dan konsentrasi outlet anaerob adalah $754,50 \mathrm{mg} / \mathrm{l}$. Sedangkan untuk Total Suspended Solid (TSS), efisiensi penurunan di dalam reaktor anaerob sebesar $16.1 \%$, dengan konsentrasi inlet rata - rata adalah $374,76 \mathrm{mg} / \mathrm{l}$ dan konsentrasi outlet rata - rata sebesar 314,50 mg/l.

Parameter nitrogen yang dianalisa dalam penelitian ini antara lain adalah amonia, nitrit, dan nitrat. Untuk parameter amonia dan nitrat, efisiensi penurunan di reaktor anaerob untuk masing masing parameter sebesar 61,7 \% dan 91,8 \%. Sedangkan untuk parameter nitrit, mengalami kenaikan dari konsentrasi inlet rata - rata sebesar $19,82 \mathrm{mg} / \mathrm{l}$ menjadi $48,64 \mathrm{mg} / \mathrm{l}$ pada konsentrasi outlet rata - rata reaktor anaerob.

\subsection{Proses Aerob}

Semula waktu tinggal didalam reaktor aerob adalah 2 hari, tetapi karena konsentrasi COD outlet reaktor aerob hampir sama dengan konsentrasi COD outlet anaerob, maka dilakukan penambahan kapasitas reaktor aerob. Sehingga waktu tinggal total untuk reaktor aerob adalah selama 3 hari. Penambahan reaktor aerob dilakukan pada hari ke 11 penelitian.

Dengan waktu tinggal tersebut, mampu menurunkan COD hingga 96,9 \%. Konsentrasi COD outlet rata - rata pada reaktor aerob sebesar 238,60 mg/l. Sedangkan efisiensi penurunan TSS adalah 79,2 $\%$, dengan konsentrasi outlet rata - rata sebesar $77,77 \mathrm{mg} / \mathrm{l}$. Efisiensi penurunan amonia pada reaktor aerob sebesar 94,1\% dengan konsentrasi amonia outlet rata - rata sebesar $172,43 \mathrm{mg} / \mathrm{l}$.

\subsection{Proses Denitrifikasi}

Fungsi dari proses denitrifikasi adalah mereduksi nitrat dan nitrit yang terkandung dalam air lindi. Pada reaktor denitrifikasi digunakan media isian batuan belerang dan batu kapur. Batuan belerang berfungsi sebagai donor proton $\left(\mathrm{H}^{+}\right)$yang akan bereaksi dengan senyawa nitrat untuk berubah menjadi senyawa antara yaitu nitrit, dan akhirnya menjadi gas nitrogen.Dalam penelitian yang kami lakukan, proses denitrifikasi menggunakan cara yang unik yaitu mereaksikan nitrat dan nitrit dengan 
batuan belerang dan batuan kapur dengan bantuan mikroba autotroph.

Waktu tinggal di dalam reaktor denitrifikasi selama 1 hari, mampu menurunkan konsentrasi amonia hingga 94,6\% dengan konsentrasi outlet rata - rata sebesar 160,03 $\mathrm{mg} / \mathrm{l}$. Efisiensi penurunan nitrat sebesar $87,5 \%$ dengan rata - rata konsentrasi outlet sebesar 224,22 mg/l. Untuk konsentrasi COD outlet reaktor denitrifikasi hampir sama dengan outlet reaktor aerob. Hal ini dikarenakan fungsi dari reaktor denitrifikasi ini bertujuan untuk mereduksi kandungan nitrit dan nitrat dalam air lindi. Konsentrasi COD outlet pada reaktor ini adalah $238,60 \mathrm{mg} / \mathrm{l}$.

\subsection{Efisiensi Pengolahan Proses Anaerob-Aerob Dan Denitrifikasi}

Di dalam penelitian ini, total waktu tinggal yang digunakan adalah 12 hari, yakni waktu tinggal di dalam reaktor anaerobik 8 (delapan) hari, waktu tinggal di dalam reaktor aerobik 3 (tiga) hari dan waktu tinggal di dalam reaktor denitrifikasi 1 (satu) hari. Dari penelitian tersebut didapatkan hasil seperti pada Gambar 8 (Lampiran) sampai dengan Gambar 14 (Lampiran). Dari hasil penelitian tersebut di atas, terlihat bahwa konsentrasi COD dari 7847,69 mg/l turun menjadi sekitar $238,60 \mathrm{mg} / \mathrm{l}$ dengan efisiensi penurunan rata rata $97 \%$. Untuk parameter TSS, konsentrasi Inlet selitar $374,76 \mathrm{mg} / \mathrm{I}$ turun menjadi $54,87 \mathrm{mg} / \mathrm{l}$ dengan efisiensi penurunan 85,4\%. Prosentase penurunan amonia dan nitrat masing masing adalah $94,6 \%$ dan $87,5 \%$.

\subsubsection{Konsentrasi COD}

Dari hasil penelitian diketahui rata - rata konsentrasi COD inlet sebesar $7907,65 \mathrm{mg} / \mathrm{L}, \mathrm{COD}$ Anaerob 774,82 mg/L, COD Aerob 473,41 mg/L, dan COD Denitrifikasi sebesar 129,38 mg/L. Grafik konsentrasi COD inlet dan outlet serta Efisiensi pengolahan pada masing - masing reaktor dapat dilihat pada Gambar 6 (LAMPIRAN).

Dari gambar tersebut dapat dilihat ketahui bahwa efisiensi pengolahan COD pada reaktor anaerob sudah diatas $90 \%$. Hal ini menandakan mikroba pada reaktor tersebut telah berfungsi secara optimal. Tetapi efisiensi penuruan konsentrasi COD pada reaktor aerob di awal penelitian sangat kecil, yaitu dibawah $5 \%$. Hal ini dikarenakan waktu tinggal di dalam reaktor aerob kurang. Pada hari kesebelas penelitian, ditambahkan reaktor aerob sehingga waktu tinggal total di reaktor tersebut menjadi 3 (tiga) hari. Dengan penambahan reaktor aerob, efisiensi pengolahan COD di reaktor aerob menjadi tinggi, yaitu $81,59 \%$.Dari rangkaian proses pengolahan secara biologis, yaitu biofilter anaerob - aerob dan denitrifikasi, rata-rata efisiensi pengolahan COD total dengan waktu tinggal 12 hari(waktu tinggal di reaktor anaerob 8 hari, reaktor aerob 3 hari, dan reaktor denitrifikasi 1 hari) adalah sebesar $98,33 \%$.

\subsection{2 pH Air Lindi Sebelum dan Sesudah Pengolahan}

Karakteristik lindi di IPAS III TPST Bantar Gebang, cenderung bersifat basa.Dari hasil pengamatan $\mathrm{pH}$ selama penelitian dapat diketahui rata-rata $\mathrm{pH}$ lindi inlet adalah sebesar 8,59, Sedangkan rata - rata nilai $\mathrm{pH}$ untuk biofilter anaerob adalah 8,5, dan biofilter aerob adalah 7,8. Tetapi ketika masuk ke dalam reaktor denitrifikasi, nilai $\mathrm{pH}$ naik menjadi 10,6. Hal ini dikarenakan limbah tersebut dikontakkan dengan batuan kapur yang bersifat basa, dan batuan sulfat yang berfungsi sebagai donor $\mathrm{H}^{+}$belum berfungsi secara optimal $\mathrm{di}$ awal penelitian. Pada hari ke 21 penelitian $\mathrm{pH}$ limbah yang keluar dari reaktor denitrifikasi berangsur turun, walaupun masih cenderung basa. Grafik pengamatan $\mathrm{pH}$ dari tiap-tiap reaktor selama penelitian dapat dilihat pada Gambar 9 (Lampiran).

\subsubsection{Konsentrasi TSS}

Rata - rata konsentrasi TSS (Total Suspended Solid) yang terdapat pada limbah lindi IPAS III TPST Bantar Gebang selama proses penelitian adalah sebesar $374,8 \mathrm{mg} / \mathrm{L}$. Setelah melalui proses biofilter anaerob - aerob, rata - rata konsentrasi TSS secara berturut - turut turun menjadi 180,1 mg/L dan 46,6 $\mathrm{mg} / \mathrm{L}$. Jadi efisiensi pengolahan total di biofilter anaerob-aerob sebesar 87,57\%.

Penggunaan reaktor denitrifikasi dimulai pada hari ke 11 (sebelas) penelitian. Pada awal limbah dimasukkan kedalam reaktor denitrifikasi, konsentrasi TSS yang keluar dari reaktor denitrifikasi justru meningkat. Hal ini disebabkan batuan kapur yang digunakan sebagai media penyangga belum bereaksi secara optimal dengan limbah, sehingga masih terbentuk endapan kapur dan sulfat di dalam limbah. Tetapi pada hari ke 18 (delapan belas) penelitian, efisiensi pengolahan reaktor denitrifikasi meningkat hingga $67,7 \%$. Jadi secara keseluruhan rata - rata efisiensi pengolahan TSS dengan menggunakan biofilter anaerob-aerob dan denitrifikasi adalah sebesar 87,5\%. Grafik konsentrasi TSS pada masing-masing reaktor dan efisiensi pengolahannya dapat dilihat pada Gambar 10 (Lampiran). 


\subsubsection{Konsentrasi Amoniak}

Kondisi aktual di IPAL lindi bantar gebang, permasalahan yang belum bisa tertangani adalah masih tingginya konsentrasi amonium, nitrat dan nitrit pada air hasil olahan IPAL.Konsentrasi Amoniak sebelum dan sesudah proses pengolahan pada tiaptiap reaktor selama penelitian dapat dilihat pada Gambar 11 (Lampiran).

Dari hasil pernelitan tersebut dapat, dilihat rata-rata konsentrasi amoniak inlet adalah 3113,12 $\mathrm{mg} / \mathrm{L}$, konsentrasi amoniak reaktor anaerob 1666,82 $\mathrm{mg} / \mathrm{L}$, konsentrasi amoniak aerob 134,67 mg/L. Efisiensi pengolahan amoniak di reaktor anaerob, aerob, dan denitrifikasi secara berturut-turut adalah $46,4 \%, 91,35 \%$, dan $55,87 \%$. Sedangkan efisiensi penyisihan amoniak total dengan menggunakan biofilter anaerob-aerob dan denitrifikasi adalah $97,56 \%$.

\subsubsection{Konsentrasi Nitrit}

Pada pengolahan IPAL lindi secara konvensional permasalahan umum yang sering terjadi adalah masih tingginya konsentrasi nitrat dan nitrit pada outlet IPAL lindi.Secara teoritis, proses denitrifikasi yang ada pada pengolahan air limbah umumnya akan berlangsung pada kondisi anoxic dimana perbandingan COD banding nitratnya tinggi, yaitu diatas $1: 10$. Karbon organik akan digunakan oleh mikroba denitrifikasi konvensional sebagai sumber energi. Pada air lindi, umumnyaangka tersebut tidak tercukupi, sehingga proses denitrifikasi tidak dapat berlangsung sempurna. Dampak yang timbul adalah tingginya konsentrasi nitrat dan nitrit di air hasil olahan IPAL.

Pada proses pengolahan secara biologis, terjadi reaksi nitrifikasi amonium membentuk nitrit. Hal inilah yang menyebabkan konsentrasi nitrit di reaktor biofilter anaerob - aerob lebih tinggi dibandingkan konsentrasi nitrit pada limbah inlet. Selain itu kondisi nitrit juga dipengaruhi oleh $\mathrm{pH}$. Apabila pH limbah basa, nilai konsentrasi nitrit cenderung tinggi. $\mathrm{pH}$ optimum untuk reaktor denitrifikasi adalah 7,4 - 7,6. Konsentrasi nitrit di inlet, reaktor anaerob, reaktor aerob, dan denitrifikasi selama penelitian dapat dilihat pada Gambar 12 (Lampiran).

\subsubsection{Konsentrasi Nitrat}

Rata - rata konsentrasi Nitrat yang terdapat pada limbah lindi IPAS III TPST Bantar Gebang selama proses penelitian adalah sebesar $2627,24 \mathrm{mg} / \mathrm{L}$. Setelah melalui proses biofilter anaerob - aerob, rata - rata konsentrasi TSS secara berturut - turut turun menjadi $475,71 \mathrm{mg} / \mathrm{L}$ dan $357,08 \mathrm{mg} / \mathrm{L}$. Jadi efisiensi pengolahan total di biofilter anaerob - aerob sebesar $86,41 \%$.

Penggunaan reaktor denitrifikasi dimulai pada hari ke 11 (sebelas) penelitian. Pada awal limbah dimasukkan kedalam reaktor denitrifikasi, efisiensi reaktor tersebut adalah 39,48\%. Tetapi pada hari berikutnya efisiensi reaktor turun drastis menjadi 7 $\%$, hal ini dikarenakan kondisi mikroba pada reaktor belum stabil. Tetapi pada hari ke - 16 dan seterusnya, efisiensi nitrat berangsur - angsur naik hingga lebih dari $60 \%$. Gambar 5.6 berikut adalah grafik konsentrasi nitrat pada masing - masing reaktor dan efisiensi pengolahannya. Konsentrasi Nitrat di dalan air lindi sebelum dan sesudah proses pengolahan di dalam tiap-tiap reaktor dapat dilihat pad Gambar 13 (Lampiran).

\subsubsection{Konsentrasi Sulfat}

Dari hasil penelitian diketahui rata - rata konsentrasi sulfat inlet sebesar $67,47 \mathrm{mg} / \mathrm{L}$, sulfat Anaerob 57,0 mg/L, sulfat Aerob 24,76 mg/L, dan sulfat Denitrifikasi sebesar 15,13 mg/L. Konsentrasi sulfatsebelum dan sesudah proses pengolahan, serta efisiensi pengolahan pada masing - masing reaktor selama penelitian dapat dilihat pada Gambar 14 (Lampiran).

Dari tabdambar tersebut dapat diketahui bahwa efisiensi pengolahan sulfat pada reaktor anaerob masih dibawah 20\%. Prosentase pengolahan sulfat tertinggi terjadi di reaktor aerob, yaitu $56,75 \%$. Konsentrasi sulfat di reaktor denitrifikasi relatif rendah, menunjukkan bahwa batuan sulfur pada reaktor ini belum bekerja secara optimal. Hal ini dibuktikan dengan masih tingginya $\mathrm{pH}$ ait di dalam reaktor denitrifikasi. Karena batuan sulfur disini berfungsi sebagai donor $\mathrm{H}^{+}$agar $\mathrm{pH}$ pada reaktor denitrifikasi bersifat netral.

\section{KESIMPULAN}

Dari penelitian teknologi proses pengolahan air lindi dengan sistem biologis anaerob, aerob dan denitrifikasi dapat ditarik kesimpulan sebagai berikut:

- Proses anaerob menggunakan reaktor biofilter dengan bahan isian sarang tawondapat mereduksi kandungan polutan organik dalam air lindi. Efisiensi yang dapat diperoleh adalah 90.16\% dengan waktu tinggal 8 hari..

- $\quad$ Proses aerob menggunakan bioreaktor dengan bahan isian sarang tawon, pada kondisi waktu tinggal 3 hari dapat mereduksi polutan organik dalam air lindi sampai $81,59 \%$

- Pengolahan air lindi dengan kombinasi proses biofilter anaerob-aerob dan proses denitrifikasi 
dengan batu kapur dan belerang dengan waktu tinggal total 12 hari yakni waktu tinggal di reaktor anaerob 8 hari, reaktor aerob 3 hari, dan reaktor denitrifikasi 1 hari dapat menurunkan konsentrasi COD dengan total efisiensi penyisihan sebesar 98,33\% .

- Kombinasi bioreaktor anaerob-aerob dan proses denitrifikasi dapat mereduksi senyawa nitrat yang terkandung dalam air limbah sebesar $88.47 \%$.

- Reaktor denitrifikasi belum berfungsi maksimal dalam mereduksi nitrit. Efisiensi yang diperoleh dalam mereduksi nitrit sebesar $48.12 \%$. Hali ini dikarenakan batuan sulfur yang menjadi bahan isian reaktor belum berfungsi secara optimal.

- Ketiga proses tersebut dapat dipadukan untuk mengolah air lindi yaitu yang pertama dengan proses anaerobik, hasil olahan anaerobik diproses dengan aerobik dan sebagai post treatment nya terakhir dengan denitrifikasi.

\section{DAFTAR PUSTAKA}

- Annonim 1, 2012. Buku Diseminasi Dan Sosialisasi Keteknikan Bidang PLP "Materi Bidang Sampah II “, Direktorat Jendral Cipta Karya , Kementerian Pekerjaan Umum.

- Annonim 2, 2007. DR 2800 Spectrophotometer Procedures Manual dengan nomor katalog DOC022.53.00725 ( Edisi 2, Juni 2007 ).

- Archer, D.B., and B.H. Kirsop,1991. The microbiology and control of anaerobic digestion, pp. 43-91, in : Anaerobic Digestion : A Waste Treatment Technology, A. Wheatly, Ed. Elsevier Appplied Science, London, U.K.

- Arvin, E., and P. Harremoes. "Concepts and Models for Biofilm Reactor Performance", Water Science and Technology. Vol. 22, No. 1/2. P.171-192. 1990.

- Barners, D., and P.A. Fitzgerald.1987.
Anaerobic wastewater treatment processes, pp.57-113, in : Environmental Biotechnology, C,F. Forster and D.A.J. Wase, Eds. Ellis Horwood, Chichester, U.K.

- Bitton G. (1994), "Wastewater Microbiology". Wiley-Liss, New York.

- Farquhar,G.J.(1989).Leachate:ProductionandC haracteristics,CanadianJournal of Civil Engineering, 16: 317-325.

- Grady, C.P.L and Lim, H.C.(1980). "Biological Wastewater Treatment", Marcel Dekker Inc. New York.

- Hikami, Sumiko., "Shinseki rosohou ni yoru mizu shouri gijutsu (Water Treatment with Submerged Filter)", Kougyou Yousui No.411, $12,1992$.

- Keenan, J.D., Steiner, R. L. and Fungaroli, A.A. (1984). Landfill LeachateTreatment, WCPF, 56(1): 33-39.

- Metclaf And Eddy (1991), "Waste Water Engineering", Mc Graw Hill.

- RoweRK,Quigley RMandBookerJR. 1997. Clayey barrier system forwastedisposal facilities. E\&FNSpon. p.I-45.

- Sahm, H. 1984. Anaerobic wastewater treatment. Adv. Biochem. Eng. Biotechnol. 29: 84-115.

- Sterritt, R.M., and J.N. Lester. 1988. Microbiology for Environmental and Public Health Engineers. E.\&F.N. Spon, London.

- Tchobanoglous, Vigil, Theisen. (1993). Integrated Solid Waste Management. McGraw-Hill, Inc. 1993.

- Viessman W, JR., Hamer M.J., "Water Supply And Polution Control ", Harper \& Row, New York,1985.

- Winkler, M.A. 1981. Biological Treatment of Wastewater. John Willey and Sons, New York.

- Zeikus, J.G. 1980. Chemical and fuel production by anaerobic bacteria. Annual Rev. Microbiology. 34 : 423-464. 


\section{LAMPIRAN}

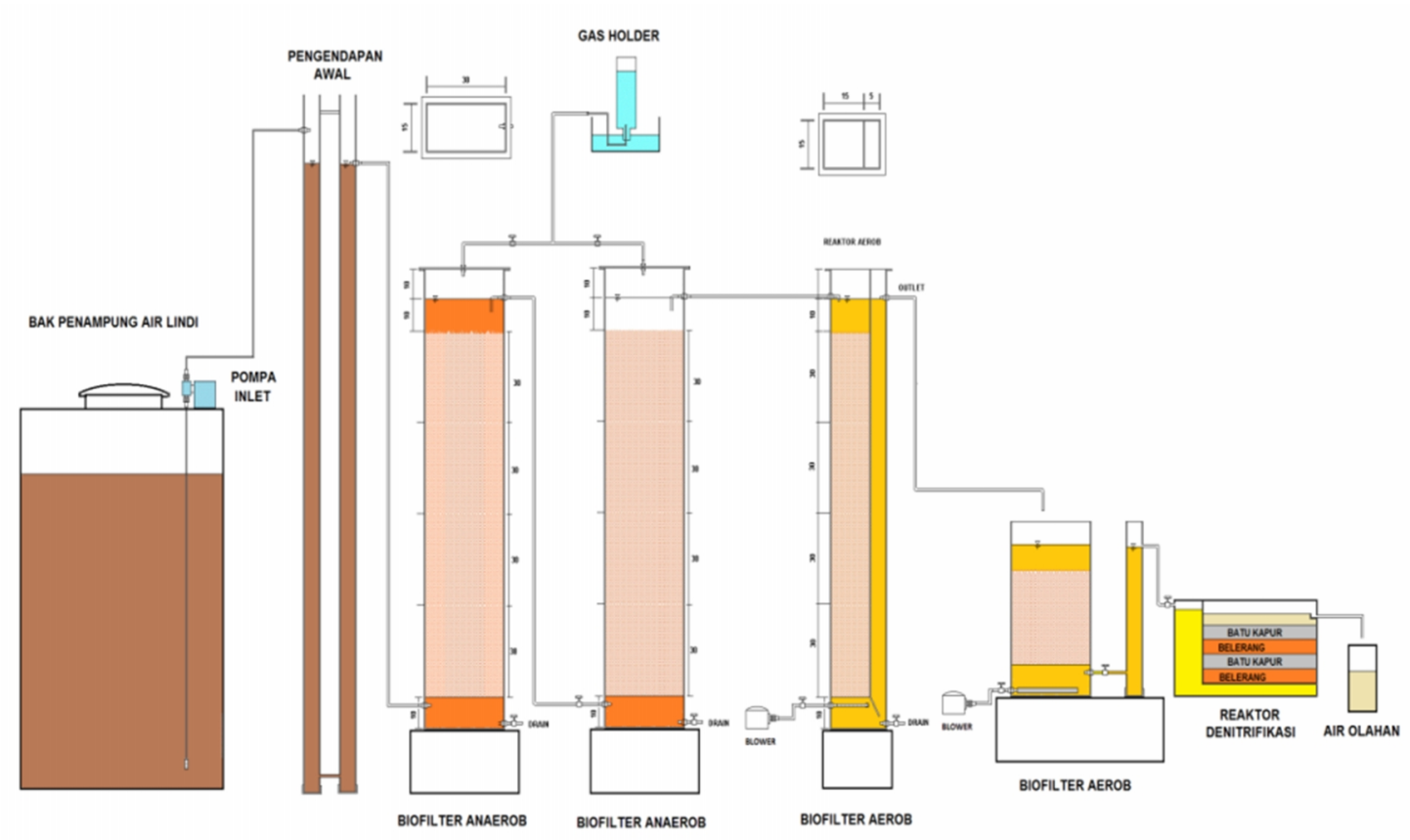

Gambar 7 : Diagram Proses Pengolahan Air Lindi Dengan Proses Biofilter Anaerob-Aerob Dan Proses Denitrifikasi Dengan Media Isian Belerang Dan Batu Kapur.

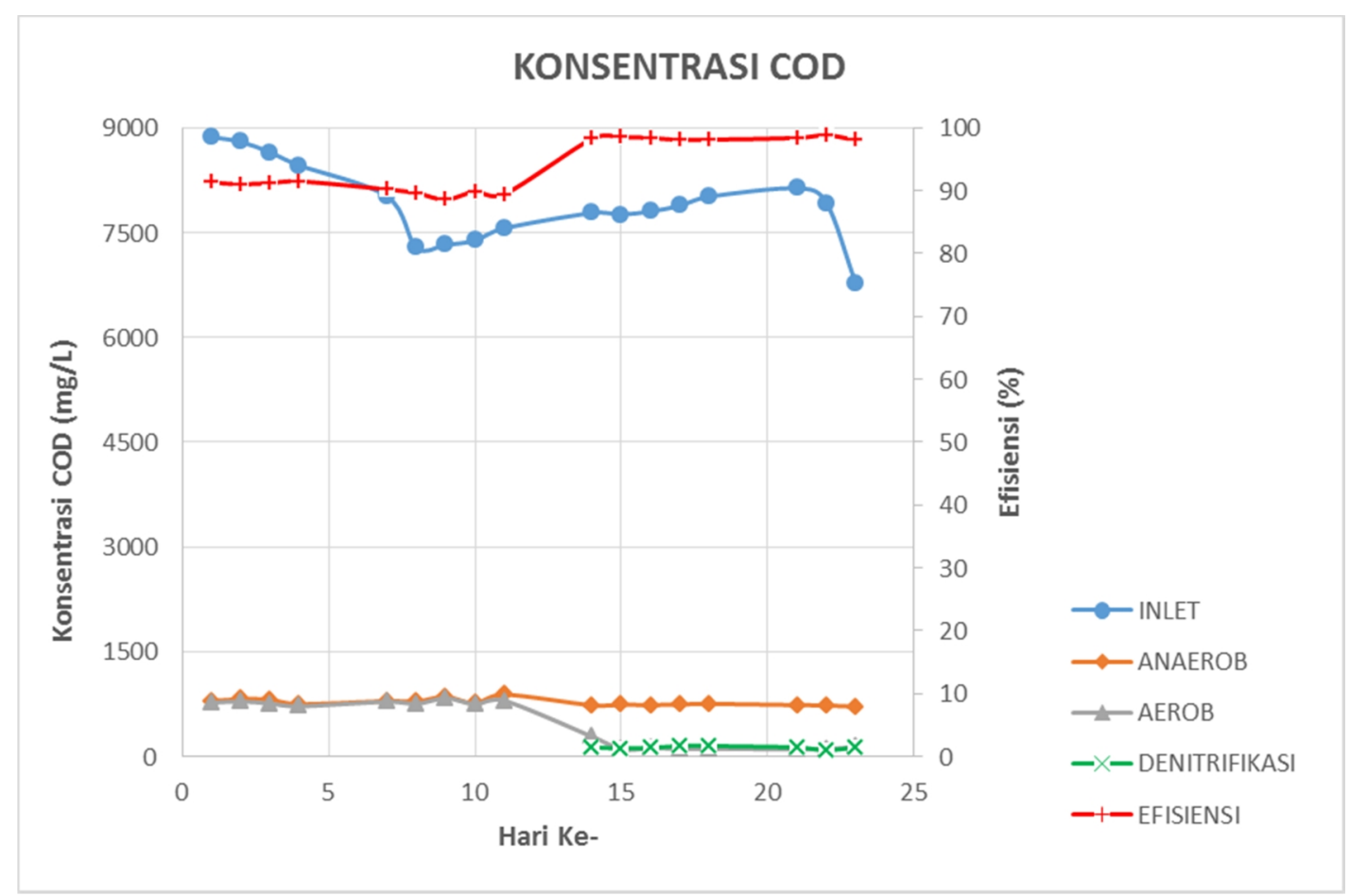

Sumber : Hasil Penelitian, 2014

Gambar 8 : Grafik Konsentrasi COD dari Masing - Masing Reaktor dan Efisiensinya. 


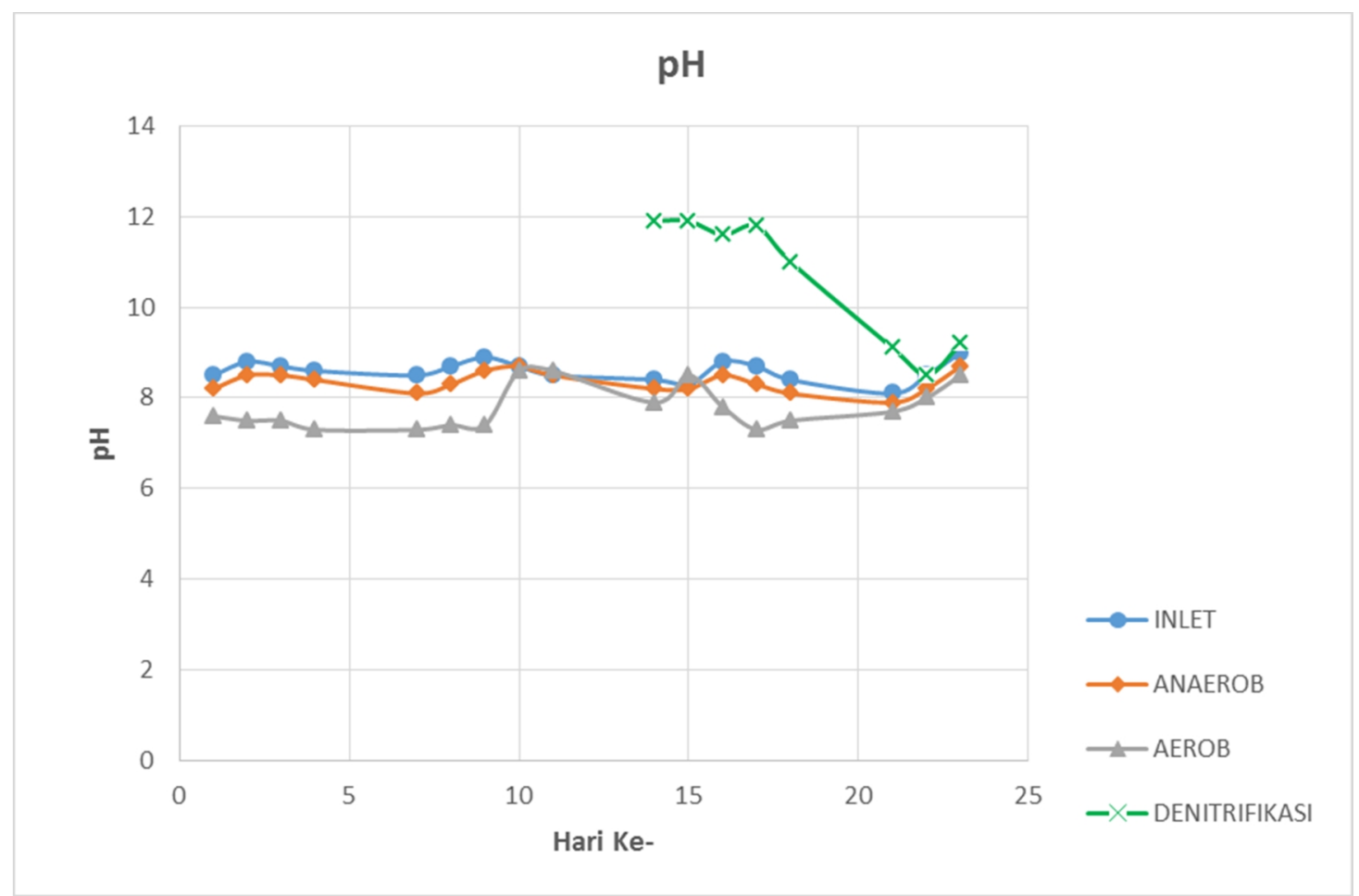

Sumber : Hasil Penelitian, 2014

Gambar 9 : Grafik Pengamatan pH dari Masing - Masing Reaktor.

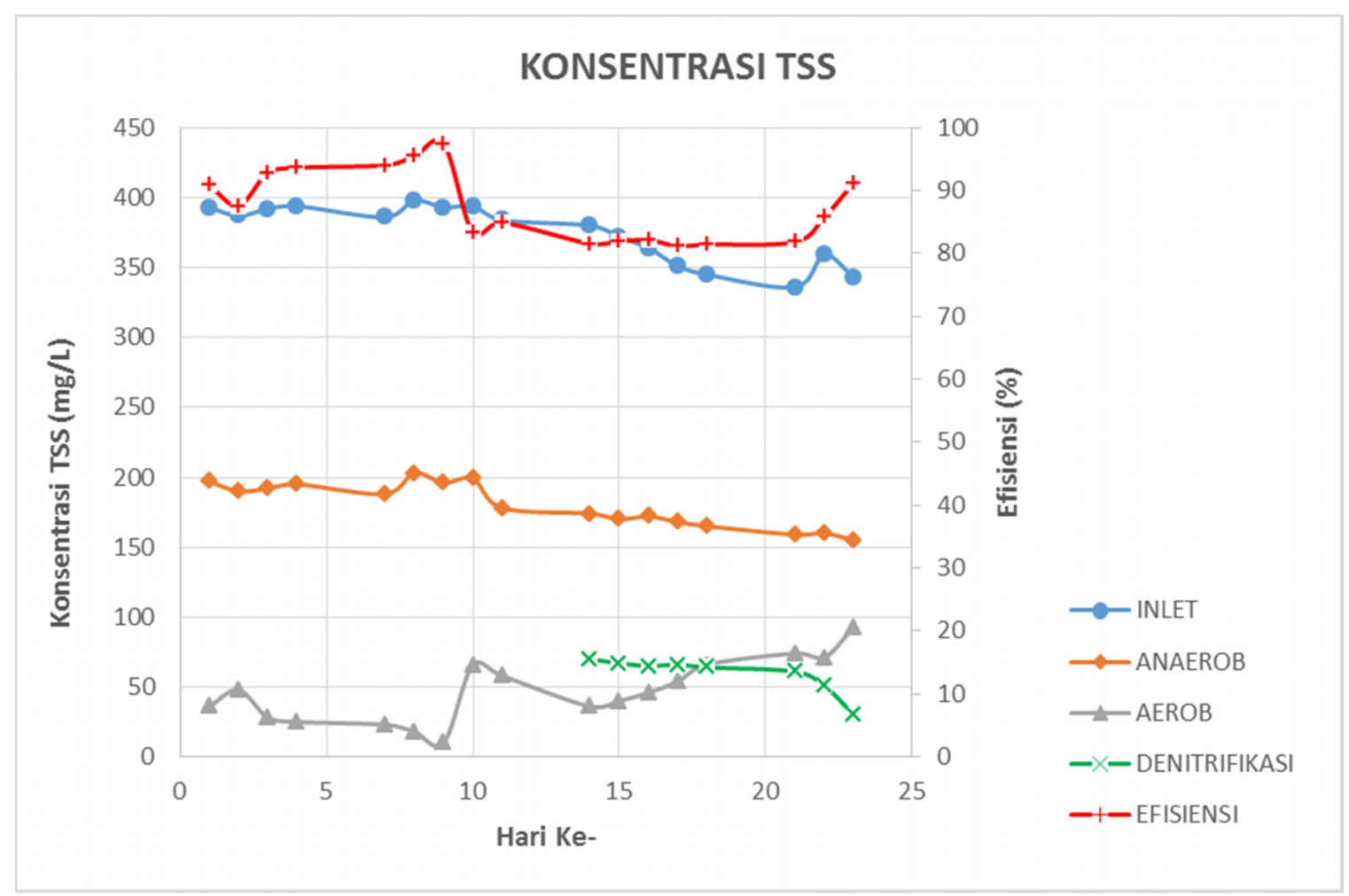

Sumber : Hasil Penelitian, 2014

Gambar 10 : Grafik Konsentrasi TSS dari Masing - Masing Reaktor dan Efisiensinya. 


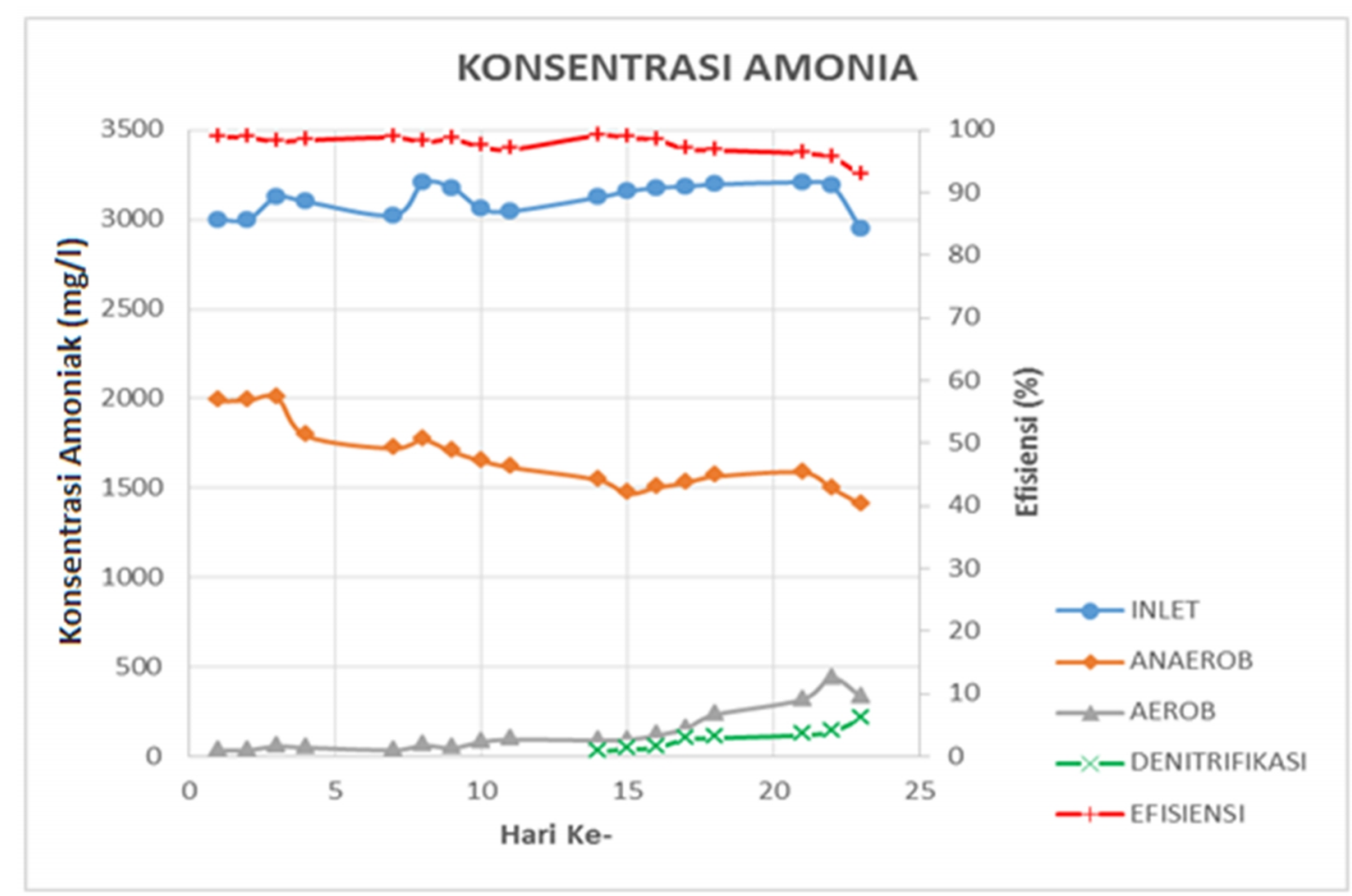

Sumber : Hasil Penelitian, 2014

Gambar 11: Grafik Konsentrasi Amoniak dari Masing - Masing Reaktor dan Efisiensinya.

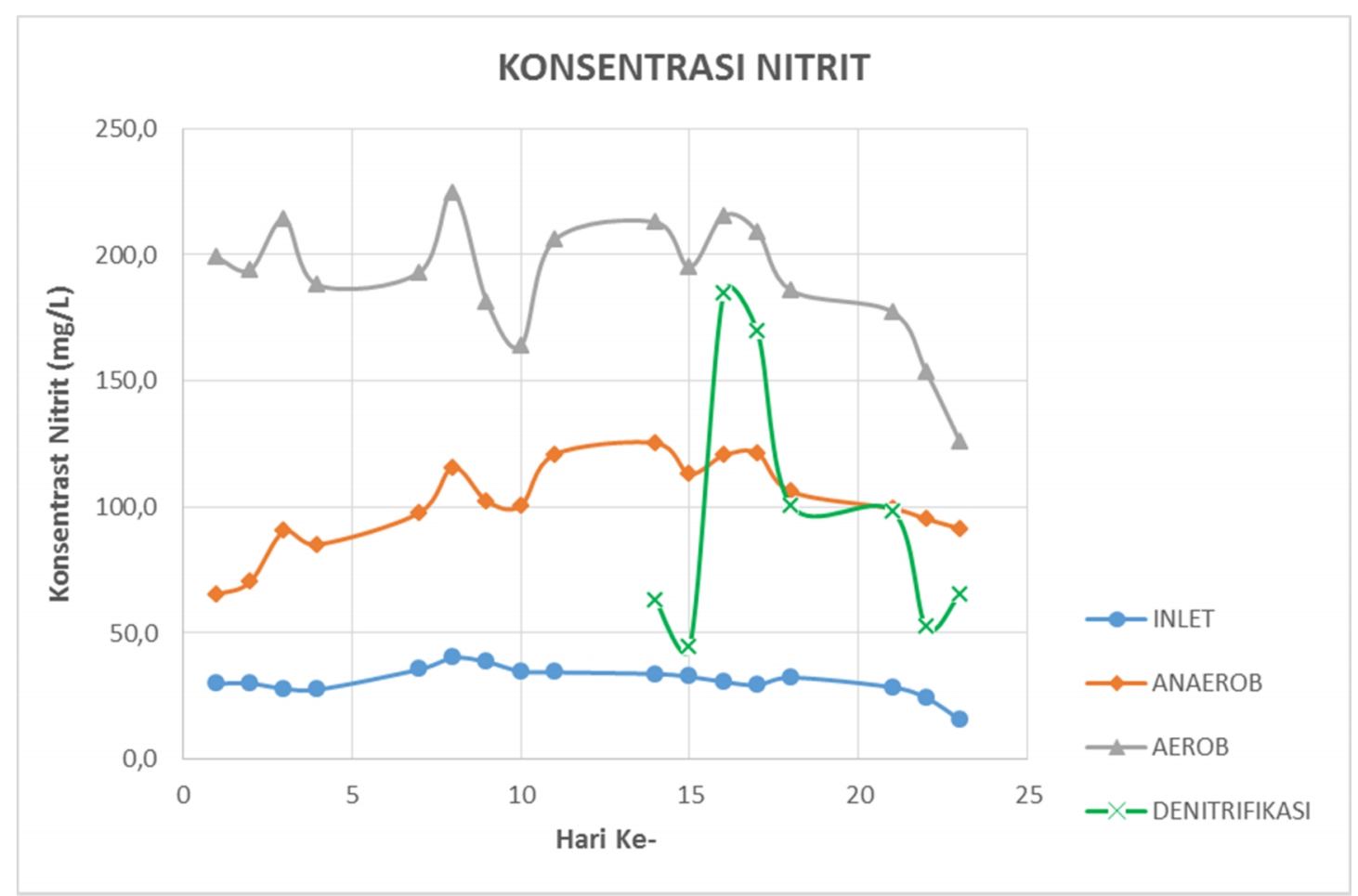

Sumber : Hasil Penelitian, 2014

Gambar 12 :Grafik Konsentrasi Nitrit pada Masing - Masing Reaktor. 


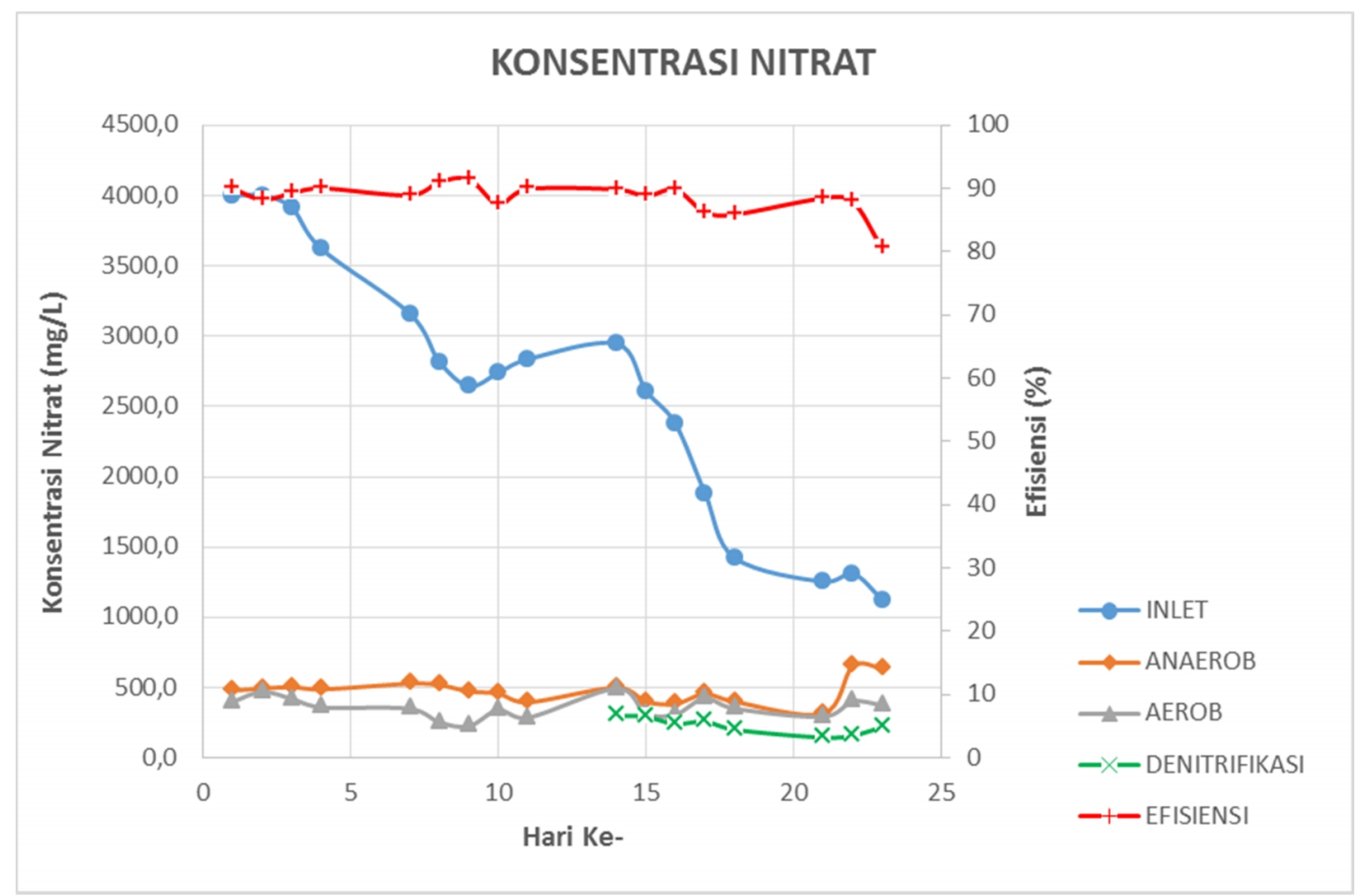

Sumber : Hasil Penelitian, 2014

Gambar 13 :Grafik Konsentrasi Nitrat dari Masing - Masing Reaktor dan Efisiensinya.

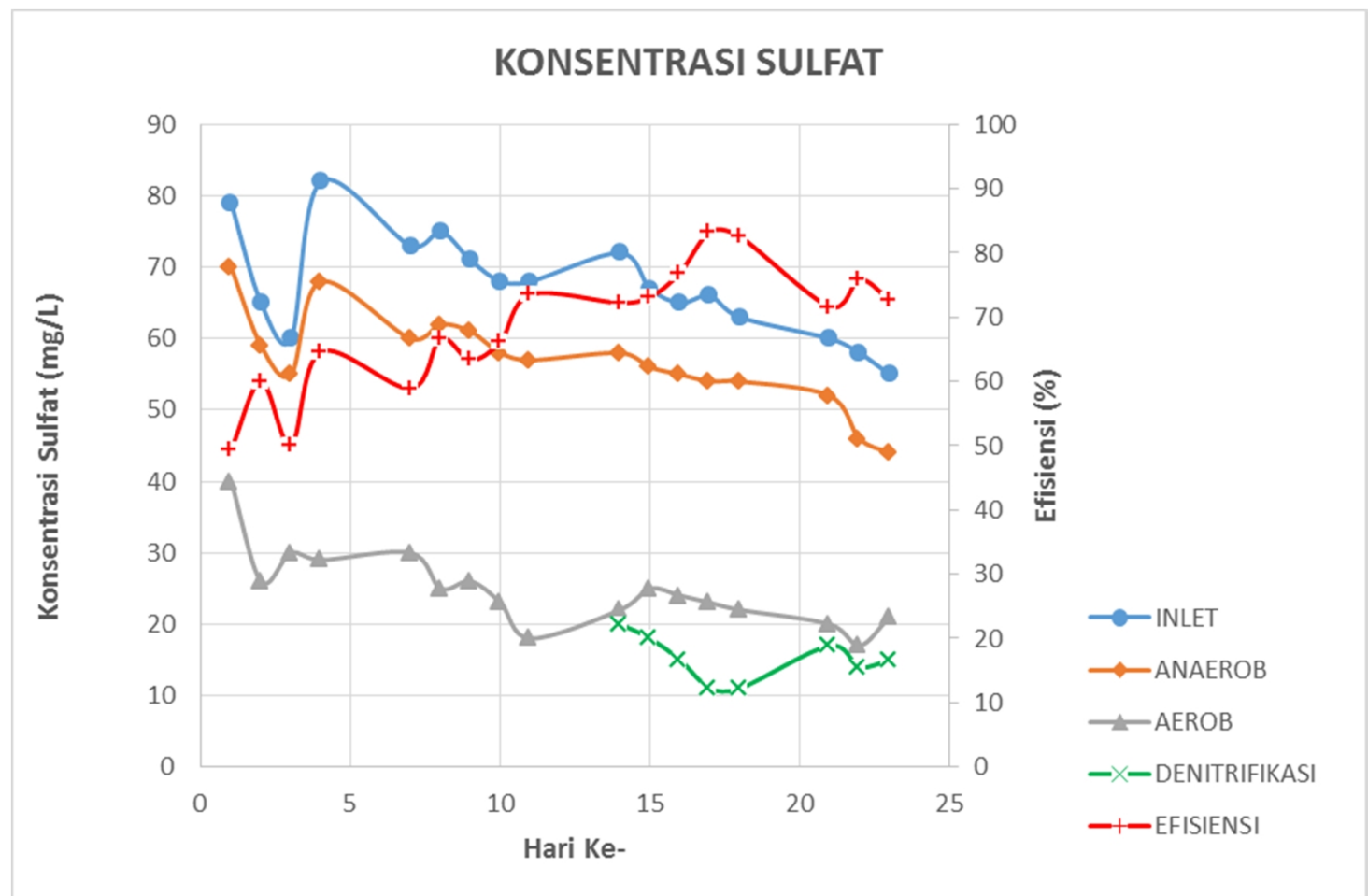

Sumber : Hasil Penelitian, 2014

Gambar 14 :Grafik Konsentrasi Sulfat dari Masing - Masing Reaktor dan Efisiensinya. 
